This is a peer-reviewed, accepted author manuscript of the following article: Aartun, I., Walseth, K., Standal, $\varnothing$. F., \& Kirk, D. (2020). Pedagogies of embodiment in physical education: a literature review. Sport, Education and Society.

https://doi.org/10.1080/13573322.2020.1821182

\title{
Pedagogies of embodiment in Physical Education - A literature review
}

Iselin Aartun ${ }^{a *}$, Kristin Walseth ${ }^{\mathrm{a}}$, Øyvind Førland Standal ${ }^{\mathrm{a}}$ and David Kirk ${ }^{\mathrm{b}}$

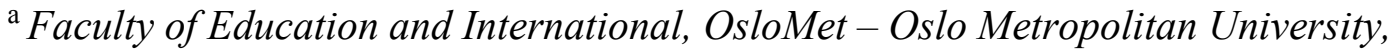

Oslo, Norway; ${ }^{\mathrm{b}}$ School of Education, University of Strathclyde, Glasgow, Scotland

Correspondence details:

Iselin Aartun,

Faculty of Education and International Studies

Department of Primary and Secondary Teacher Education

Postal address:

OsloMet - Oslo Metropolitan University

P.O. Box 4 St. Olavs plass

N-0130 Oslo

E-mail address:

iselin.aartun@oslomet.no 


\section{Pedagogies of embodiment in Physical Education - A literature review}

\section{Abstract}

Physical education puts the body center stage. Embodiment has emerged as a concept that broadens the focus on the body beyond the dualistic natural scientific point of view. Research into embodied learning and embodiment has had various focuses, including the sociological aspects of embodiment and the embodied experiences of students. This article is a literature review of peerreviewed empirical studies aiming to explore empirical research on pedagogies of embodiment in physical education. We ask what characterizes the empirical research literature on pedagogies of embodiment in physical education, and what implications for teaching and learning we can find in this literature. Forty-two studies met the criteria and were included in the review. Based on a thematic analysis of the studies, two main themes emerged. The first theme, 'enabling critical reflection,' highlights that physical education can contribute to the development of critical thinking skills among pupils and provide them with safe spaces to discuss 'taken for granted' understandings of gender, health, and body ideals within physical education. The second main theme, 'Exploring (new) movements,' shows how pupils' exploration of (new) movements can contribute to the development of body awareness and meaningful experiences. Physical education taught after principles of pedagogies of embodiment involves pupilcentered approaches and inductive approaches to teaching. These approaches give pupils the opportunity to be involved in choosing activities and creating content. Pedagogies of embodiment place focus on the importance of reflection before, during, and after activities in physical education, and expand the repertory of activities that physical education may include. In this way, 
pedagogies of embodiment may facilitate embodied learning, empowerment, and positive experiences of being in movement. Future research should investigate further the possibilities pedagogies of embodiment gives for teachers and learners, and how the potential to challenge traditional pedagogy can be developed.

Keywords: embodiment, pedagogies, physical education, critical reflection, movement exploration, experience, empowerment 


\section{Introduction}

Physical education is by its very nature a school subject that puts the body center stage (Armour, 1999; Connolly, 1995; Stolz, 2015). With certain historical exceptions, the traditional way of understanding and theorizing the body in the area of physical education is heavily influenced by the natural sciences (Pronger, 1995). While the natural scientific approach to the body has facilitated immeasurable progress in combating disease and pain, it also has certain negative consequences. The view of the body advanced by the natural sciences is described as dualistic in the sense that it presumes a clear separation between the physical body and the mind (Leder, 1992). Furthermore, the natural scientific viewpoint treats the body as a machine-like entity (Tinning, 2010), a technological object to be trained and perfected (Pronger, 1995), which may have alienating consequences for individuals (Wright, 2000).

Embodiment has emerged as a concept that broadens the focus on the body beyond the natural scientific perspective (Cheville, 2005). Central to embodiment is the understanding that the body is not only connected to subjective experiences - rather, it is the ground of such experiences (Standal, 2020). Since at least the 1970s, embodiment and corresponding terms such as embodied learning have been employed in the physical education literature (Arnold, 1979; Whitehead, 1990). Research into embodied learning and embodiment has had various foci. One line of research emphasizes what Shilling (2010) calls body pedagogies, how societal norms are translated into institutions such as schools via policies, messages and practices. This perspective emphasizes the sociological aspects of embodiment, e.g. the pedagogical work performed on students' bodies by physical education teachers. Another perspective analyzes the embodied experiences of students (Bailey \& Pickard, 2010; Brown \& Payne, 2009; Standal \& Aggerholm, 2016). 
Shilling (2010) points out that there is a 'theoretical cleavage' (p. 164) between Foucauldian-inspired analyses and more phenomenological approaches to embodied experiences. More specifically, Shilling (2010, p. 164) highlights the tension that 'exists between the causal determinacy that tends to be associated with Foucault's approach, and the concern with experience as a phenomenon in its own right that cannot be reduced, a priori, to any discourses or other "social facts." Research into sport and physical culture has also drawn on the notion of embodiment to explore and critique embodied practices, such as physical activity promotion campaigns and digital surveillance tools (Depper, Fullagar, \& Francombe-Webb, 2019; Francombe-Webb \& Toffoletti, 2018; Rich, 2018). This line of research turns our attention beyond the body as something we have towards addressing the body as something we are, to us as human beings. An important theoretical point is therefore that as embodied human beings we learn and are socialized into both having and being our bodies.

Oliver and Kirk (2016) state that while notions of the body in culture are present in the physical education literature, various understandings of 'the body' are evident. Framing these various approaches as pedagogies of embodiment, Oliver and Kirk go on to state that 'pedagogies of embodiment in which the study of the social construction of the body becomes an essential part of the curriculum are key to the development of transformative forms of PE' (p. 310). They use activist research working with girls in physical education as an example of pedagogies of embodiment. However, the potential range of the concept embodiment is clearly wider than that. Therefore, drawing on the work of Oliver and Kirk (2016), and acknowledging the less than uniform way embodiment is theorized, it seems vital to clarify what one talks about when one talks about pedagogies of embodiment in the context of school physical education. Moreover, by systematically analyzing empirical work on pedagogy of embodiment, we aim to 
highlight processes of teaching and learning that seek to counter the traditional, dualistic teaching methods that have informed physical education for many decades (Kirk, 2010). Ultimately, what is at stake here is pupils' learning about themselves as embodied human beings. The purpose of this review is, then, to explore empirical research on pedagogies of embodiment in physical education. More specifically, we ask what characterizes the empirical research on pedagogies of embodiment in physical education, and what implications for teaching and learning can we find in this literature.

\section{Method}

This literature review is narrative in form and aims to present an overview of previous and current empirical research literature on the topic of 'pedagogies of embodiment' in physical education (Grant \& Booth, 2009, pp. 99-100). The search process was carried out systematically. Unlike many narrative reviews, we wanted to use systematic search methods and specific criteria for selection of research papers. One reason was to gather all the empirical pedagogical work that has been done using 'embodiment' as a concept. The other reason was that we wanted to be open to the reader, to ensure our searches could be replicated.

In the first phase, we researched three relevant and subject-specific databases using a search string consisting of the key words 'embodiment' and 'physical education'. ${ }^{1}$ At this stage, we wanted to collect all relevant articles on the topic, and therefore searched using title, abstract and keywords. We considered using a more complex search string with several keywords and proximity operators, but lower complexity provided a higher number of articles and enabled us to sort the articles

\footnotetext{
${ }^{1}$ We used the search string (Embodi* AND "Physical educat*"), and searched in the databases Eric, SportDiscus and Scopus.
} 
manually, instead of leaving that step to the computer or the databases. For this review, only results that included both the concept of embodiment and the topic of physical education were of interest ${ }^{2}$. Our search process resulted in 474 hits. We imported the results into the application EndNote and removed duplicates both manually and using the program. The number of articles was reduced to 272 . We then sorted the articles by studying titles and abstracts, comparing them against our inclusion criteria (see Table 1). For some articles, it was necessary to study the full text. This process narrowed our results down to 26 articles.

[Table 1 near here]

In the process of studying these articles, we realized that we were missing important studies that we knew about on the same topics. One reason for this may be that 'embodiment' as a concept is defined in various ways in different fields. In addition, the phenomena the concept of embodiment refers to is not easily put into words. Authors (drawing on particular disciplines) therefore use a range of terms such as. 'somatic grasping', 'body awareness', 'subjectivity', 'bodily knowledge' and 'corporeality', to try to explain the phenomena of embodiment. This may explain why the initial search in the databases missed important papers.

The next phase therefore consisted of a manual search through seven relevant core journals in the physical education pedagogy field, in order to check whether we had missed any relevant and recent material during the database search. The manual search was conducted across the last five years in order to identify the most recent and up to

\footnotetext{
${ }^{2}$ Research on body pedagogies relevant to physical education are also to be found in journals other than those centred in this paper, and may lead to additional insights into processes of embodiment.
} 
date publications in the journals Physical Education and Sport Pedagogy, Sport, Education and Society, Journal of Teaching in Physical Education, European Physical Education Review, Research Quarterly for Exercise and Sport, Curriculum Studies in Health and Physical Education and Quest. Nine articles from this manual search met the inclusion criteria.

In the third phase, articles that we considered relevant, but that did not show up in any of our searches, were examined. Seven articles from this snowballing process met the inclusion criteria.

The total number of articles included is 42 . We studied all the articles from all three phases carefully in full text, using a thematic analysis (Braun \& Clarke, 2006). First, we looked for terms frequently used in relation to embodiment, to arrive at an overview of the content. We then identified and compared the aims, methods, findings and implications in the studies, to identify the main themes and topics. We searched every document for linking words to "embodiment" or "embodied". Examples of the most frequent linking words are embodied identity, -subjectivities, -gender, -meaning, culture, -faith, -discourses, -practices, -exploration, -learning, -knowledge, disembodiment. Examples of concepts that seem to overlap embodiment (theoretically and content wise) are "somatic grasping", "body consciousness" and "knowing in moving". Concepts like habitus and corporeal sensations also relate to embodied practices and experiences. Finally, we synthesized our thematic findings into two themes: A. Enabling critical reflection, and B. Exploring (new) movements.

\section{Findings}

The articles included are relatively recent. Only one of the studies was published before 2000. Twenty-six of the studies $(62 \%)$ were published within the last ten years. This tells us that the focus on pupils' embodiment is a fairly new area of study, and that 
research in this field is sparse, but growing. The first authors are mainly employed at universities in the UK (31\%), the USA (24\%), Australia (19\%) and Sweden (14\%). Fourteen journals are represented in this review. Sport, Education and Society published nearly one third of the articles included (12 out of 42, or 28\%), and Physical Education and Sport Pedagogy published 10 out of 42 (24\%). Publications in these two journals thus make up over half of the articles, and there is reason to believe that they are dominating publishing on this area of research.

This paper presents the main thematic findings from these articles. The themes are based on the articles' suggested implications for physical education pedagogy, and can be seen as important elements of pedagogies of embodiment. A common characteristic of these studies is that they underline the need for new practices in physical education that challenge the status quo of traditional practices.

\section{A. Enabling critical reflection}

In this section, we show that many of the articles in this review have studied pupils' embodied experiences and identity work in physical education. These studies stress that there is a particular need for pedagogies that can challenge 'taken-for-granted' understandings of gender, health, and body ideals in physical education. It is argued that teaching in physical education should include a focus on developing pupils' critical reflection. The section is divided into two parts. First, we focus on empirical studies that investigate pupils' embodied experiences in physical education. Thereafter, we present studies that has focused more on how we can enable and improve the embodied experiences for pupils in physical education. The studies that focus on enabling and improving the embodied experiences of pupils have applied either a participatory action research design or an activist approach to physical education. 
The picture drawn in this review is that girls (and some boys) experience alienation in physical education, and that pupils protect their identities by not taking part in activities. Notions of normality, feeling accepted, and avoiding embarrassment influence their embodied identity work in physical education (e.g. Gorely, Holroyd, and Kirk (2003) and Kirk and Tinning (1994)). Studies have shown how girls' fear of being overweight operated as an (unhealthy) disciplining practice within the field of physical education. The findings also show that the emotional dynamics of fear are used as a threat by both teachers and girls themselves to incite or motivate participation in physical education (Windram-Geddes, 2013, pp. 48-49). Unhealthy disciplining practices are also found in other studies (Fisette, 2011; lisahunter, 2004). For example, Fisette (2011) Foucauldian-inspired analysis finds that pupils primarily focus on the physical aspect of the body when navigating embodied identities in physical education . Disciplining practices emerge from self-surveillance and (the feeling of) surveillance by others, and the girls compare themselves to socially constructed body ideals. The studies presented above indicate that physical education lacks opportunities for pupils to express their embodied identities, and that makes it difficult to move beyond the objectification of the body. Windram-Geddes (2013, pp. 48-49) psychological study of how embodied emotions relate to obesity discourses discusses how developing an objectified perception of the body may contribute to an alienated relationship to one's own body and addresses the need to challenge dualistic and normalized understandings of health. Since this is difficult, the author suggests that it must be achieved through a slow and sensitive approach, questioning conventional understandings of what it means to have good health in a conscientious way.

Several studies have focused specifically on ethnic minority pupils' embodied experiences in physical education contexts. Most of these studies are positioned within 
feminist theory and use the concept of intersectionality to explain the physical education experiences of ethnic minority girls. The studies show that this is a heterogeneous group, which navigates and negotiates the spaces of physical education and physical activity in various ways. An example is Stride's (2016) study of British South Asian girls. The study is positioned within black feminism and shows how the girls demonstrate resistance to the official discourses of physical education. In their broader activity spaces outside of school, they develop their agency by creating their own practices according to what best meets their own needs, by avoiding focus on, for example, competition and competency (Stride, 2016, p. 693). Similar findings are seen in other studies, where several fields outside school play a role in the development of pupils' physical culture and embodied identity. The girls are physically active in settings they find relevant, inclusive, caring, and connected to their identities. Examples of such settings are doing yoga in their homes, or playing ball games and driving scooters outside in their backyards. These settings outside of school felt like safe spaces without the disciplining "public gaze” (Azzarito \& Hill, 2013; Dagkas \& Hunter, 2015; Hill \& Azzarito, 2012).

Although there is a larger focus and concern about ethnic minority girls' marginalization in the subject, some studies have focused on boys and their identity work. The studies indicate that ethnic minority boys feel a pressure to develop strong and skilled bodies in order to live up to hegemonic masculine and racialized ideals. Boys who do not have the body types that are traditionally valued risk being marginalized and placed lower in the social hierarchy (Hill, 2015; Tischler \& McCaughtry, 2011). Tischler and McCaughtry's study focused on the social construction of masculinity and used hegemonic masculinities and feminist poststructuralism as theoretical lenses to understand their findings. The study stressed 
that physical education should facilitate critical consciousness among boys, to help them see how gender and masculinities are socially constructed. They suggest that in order to stimulate such critical reflection, pupils must be provided with experiences that allow them to dispute gender discourses and reflect upon their own views about physical competencies. The practical activities suggested are, for example, innovative or challenging forms of physical activity like outdoor activity and dance. Through such activities, it may be possible to create spaces that encourage boys to be more sensitive toward each other and help them identify with other non-hegemonic masculinities.

In discussions about how physical education can become a safe place, it is argued that pupils must be provided with the opportunity to create alternative narratives and selves and with spaces to experience and articulate their active identities (Hill \& Azzarito, 2012). Furthermore, it is suggested that teachers create a body-centered curriculum to support girls' management of the body in the public gaze. By strengthening the physical cultural link between home and school, and by valuing a broader spectrum of activities, the authors presume that girls can be assisted in developing identities as moving bodies (Azzarito \& Hill, 2013, p. 371). A more studentcentered curriculum and working with pupils can help to understand their thoughts and feelings, and the diverse body identities and practices that reflect their habitus (Oliver \& Lalik, 2001). In addition, some studies suggest that pedagogical practices should reflect the variety of cultures, and that teachers must be sensitive toward culturally diverse embodied values (Dagkas \& Hunter, 2015, p. 556). Intercultural understanding allows teachers and pupils to adopt inclusive pedagogical practices. Such practices involve respecting the diversity of lived experiences of being, for example, Muslim in a predominantly White Christian culture, being able to bridge differences, and making the learning environment safe. Practical measures for teachers may include being flexible 
and respecting individual needs for practical adjustments and individual agreements, in order to make participation possible for all pupils (Benn, Dagkas, \& Jawad, 2011, p. $31)$.

To summarize, the empirical studies presented above are concerned with pupils' embodied experiences and identity work in physical education. Most of these studies have been positioned within feminist- and critical theory, which promotes justice and equity between gender, sexuality, ethnicity, and disability amongst others. The feminist theories used in these studies provide insight into how the female body is objectified and demeaned in society. Feminist theories have inspired educators to make the body a focal topic in school curricula, in order to support girls' opportunities to examine their experiences of their bodies; identifying what they find important, interesting, and problematic and so on (Oliver \& Lalik, 2001, p. 305). Garrett (2004, p. 226) refers to how MacDermott (1996) uses the term "physicality" as a conceptual tool to understand how we experience ourselves physically, focusing on the complex interplay of the body and self. Garret (2004, page 226, with references to Theberge, 1987; Gilroy, 1989; Wright \& Dewar, 1997) highlights that the "emancipatory potential of physical education lies in the opportunity it provides for young women to experience bodily power, physical skill and expertise". A critical theoretical framework has enabled researchers to identify the cultural discourses that inform adolescents' experiences of their bodies, and their learning about gender-appropriate physical activity in physical education contexts (Azzarito \& Solmon, 2009, p. 175; Garrett, 2004, p. 232). By deploying feminist- and critical theory, scholars have focused on improving the embodied experiences of female students in Physical Education. The studies conclude that there is a need for new approaches that challenge the status quo and enable critical reflection. 
In the following paragraphs, we focus on new approaches to physical education; studies that focus on how we can change physical education to better meet the need of all pupils. These studies have applied either a participatory action research design or an activist approach to physical education. The activist approach developed by Oliver and Kirk (2015) is rooted in feminist poststructural and critical theories with the goal to empower students who experience marginalization in and through physical education.

A common characteristic of these studies is a focus on empowering pupils and creating safe spaces for embodied learning and identity work. The researchers work with teachers and pupils and give participants substantial agency in the research process. Another common characteristic is that the researchers try to facilitate critical reflection and guide teachers and pupils in the process of revealing the hidden curriculum about the body. A central focus is how media influences pupils' embodied understanding of gender, health, and body ideals.

An early contribution to this field of research is the study by Oliver and Lalik (2001) in which they use images of the body from popular culture (magazines) to engage girls in critical inquiry about the body. The study is positioned within poststructural feminism and focus on how the authors and participants were coconstructing bodily knowledge and reflected critically on this knowledge. In Oliver and Lalik (2004b), the researchers worked with girls in single-sex physical education classes to examine the development and implementation of a curriculum focusing on girls' bodies, to help the girls name the discourses that shape their lives and regulate their bodies. The study concluded that many girls found the process difficult, and the researchers struggled to find ways to teach the girls the process of critique without imposing the researchers' views upon them (Oliver \& Lalik, 2004a, 2004b). Another project aiming to enhance pupils' ability to reflect critically on their embodiment in 
relation to the media's fabricated body narratives is the approach called "Body Curriculum" by Azzarito, Simon, and Marttinen (2016). Positioned within third wave feminism focusing on gender and diversity (referring to Butler 1990; Howson, 2004; McLaren, 2002), the researchers conducted a participatory visual research project where they incorporate a 'Body Curriculum' into a fitness unit in an American high school class. The participants produce visual diaries and written reflections, together with interviews using photo elicitation (2016, p. 58). Although the participants rejected media narratives of idealized bodies, their desire to obtain a certain body shape was still in line with normative White standards (2016, p. 67). The authors highlighted that it is important to consider the length of such programs, in order to have enough time to destabilize learners' embodiment of the normal/abnormal dichotomy.

Another characteristic of these studies is that they work with students and empower them by providing them with spaces to take action. An example of such projects is Oliver and others' work with pupils who disengaged from physical education, to help them identify barriers to participation and co-create the physical education curriculum with pupils (Enright \& O'Sullivan, 2012; Enright \& O’Sullivan, 2010; Oliver \& Hamzeh, 2010; Oliver, Hamzeh, \& McCaughtry, 2009). Another example is Fisette and Walton's studies $(2014,2015)$ 'If You Really Knew Me...' and 'Beautiful You.' These studies build on previous activist work by Oliver and others. After working with media consumption logs, the participants created their own project intending to help their classmates feel more confident in physical education. They created a video based on the TV show If You Really Knew Me, where different people were challenged to talk about how they felt, and the others could respond if they had ever felt the same way (Fisette \& Walton, 2014, p. 150). In 'Beautiful You,' the pupils created after school programs (Fisette \& Walton, 2015, p. 70). The girls in the study 
indicated that they felt a sense of empowerment through social action. Fisette and Walton $(2014,2015)$ argued that facilitating a critical body pedagogy can contribute to explicating the hidden curriculum of inequalities and social groupings. If integrated into physical education settings, critical body pedagogy may help to create safe spaces to access pupils' voices, help them explore their embodied identities, and empower them to speak up and take action about embodiment and inequality (Fisette \& Walton, 2015, p. 75).

In engaging pupils in conversations about gender, health, and body ideals and inviting them to take part in co-constructing the curriculum, the aim of much of this work has been to empower pupils to become agents of social change. A central tool in this process is to develop pupils' critical reflection skills. However, critical reflection skills, while necessary, are not sufficient within pedagogies of embodiment. The reasons why critical reflection by itself is not sufficient to constitute a pedagogy of embodiment is because physical education is an embodied subject in the school curriculum, and movement is at its heart. The problem with traditional practices in physical education according to Fitzpatrick \& McGlashin (2017) and Standal (2015) these practices are not inclusive and do not accommodate, far less celebrate, diversity. They seek instead to straighten out any 'queerness' (Standal, 2015) that children with bodies and movement capabilities that do not fit the norm bring to physical education classes. In addition to develop critical reflection skills, pupils' need to be given opportunities to feel and explore (new) movements.

\section{B. Exploring (new) movements}

Empirical research on pedagogies of embodiment in physical education does not only revolve around enabling critical reflection about gender, body ideals, and health. The research also highlights embodied exploration of being in movement, and the need to 
reflect upon these experiences. In this section, we will present how exploring (new) movements can contribute to developing body awareness and meaningful experiences. We will also draw attention to how movement exploration has been used as a tool to obtain other goals: developing trust, democracy, and challenging stereotypes.

Exploring 'capability to move' may help pupils develop body awareness and motoric competencies (Nyberg, 2014). Working from a phenomenographic perspective, Nyberg \& Meckbach (2017, p. 11) understand capability to move as a form of practical knowledge where there is no distinction between physical and mental skills (Nyberg \& Meckbach, 2017, p. 11). A starting point for this explorative approach is a critique of traditional views of skill development. The main difference between traditional views and more recent theories is that pupils through developing body awareness may discover what they experience as comfortable and meaningful movements and - in turn - develop their movement preferences. Through the exploration of movements and work with analyzing aspects of movement, practical knowledge ('knowing how') may be developed. Through studies where pupils explore and investigate different kinds of movement activities, they practice analyzing sensations and feelings while moving. The aims are to explore the object of learning —a movement called 'house-hopping' (Nyberg \& Carlgren, 2015), the landscape of juggling (Nyberg, Barker, \& Larsson, 2020) and running (Bergentoft, 2018). In these projects, teachers and pupils collaborate to develop strategies to analyze sensations and feelings while moving, to develop sensitivity and explore body awareness. In these studies, pupils develop abilities to identify critical aspects of movement. Bergentoft (2018) suggests that learning studies may facilitate embodied exploration of body awareness that can be used as an educational means to enhance movement capabilities (p. 1). Similarly, Nyberg and 
Mechbach state that exploring ways to move should be an educational goal in physical education (2017, p. 12).

The Movement-Oriented Practising Model (MPM) is a pedagogical model for physical education, outlined by Aggerholm, Standal, Barker, and Larsson (2018). Some central learning outcomes and teaching strategies are presented as related to the model: “(1) acknowledging subjectivity and providing meaningful challenges, (2) focusing on content and aims of practicing, (3) specifying and negotiating standards of excellence, and (4) providing adequate time for practicing” (Aggerholm et al., 2018, p. 197). Empirical research on experiences from implementing the MPM model aimed to study how this model may contribute to dispositional development in students' ways of moving, their approaches to practicing and performance, and how they described their own processes of learning (Lindgren \& Barker, 2019, p. 534). The study showed that students' dispositional development was personal and unique, at times difficult to observe for teachers and others, and time intensive (Lindgren \& Barker, 2019, p. 544).

The articles in this review show that exploring non-competitive activities may facilitate pupils' enjoyment of movement. Non-competitive activities may therefore reduce the risk of limiting some pupils' participation because of the pressure to perform (Hills, 2007, p. 332). Working in the field of disability, Fitzgerald (2005) argued that developing motoric competencies should focus on educational aspirations rather than identifying performances (p.55). Giving pupils the opportunity to be self-directed learners as collaborative problem-solvers may open up a wider range of movement possibilities and practices (Wright, 2000, p. 47). Some of the articles suggest that a reduced focus on competition in sport activities may increase trust and democracy, and thus offer the potential for social and moral learning in schools (Hills, 2007; Light, 2007; Tischler \& McCaughtry, 2011). Specific models for teaching games and sport 
(e.g. TGFU, Game Sense or Sport Education) are suggested, because they emphasize learning in cooperation rather than learning in competition (Light, 2007).

Exploring (new) movements may facilitate reflection and discussion about how pupils understand concepts like ability and skills. In physical education, there seems to be a hierarchy of skills, where certain skills are seen to be more valuable than others (Wright, 2000). In Evans, Bright and Brown's (2015) Bourdieu-inspired study, the focus was on able-bodied pupils' experiences of wheelchair basketball. The study showed that the pupils' explorations of new ways to move gave them insight into what it is like to engage in a sport typically played by disabled people. Exploring disability sport may challenge able-bodied pupils' ideas of what ability ("to be able") means. Such embodied experience may broaden their understanding of what it means to be able and skilled, expanding narrowly defined measures of performance and "the sporting body" (Fitzgerald, 2005, p. 55).

Pupils experience some activities in physical education as gendered, believing that there exist gender-appropriate activities and movements (Azzarito \& Solmon, 2009; Gard, 2003; Garrett, 2004). Developing skills through early learning experiences may be an important step in helping pupils dare to try new, transgressive activities (Garrett, 2004, p. 235). New movement experiences may inform how they move and how they like to move, and may challenge stereotypical attitudes and the 'taken-for-grantedness' of bodies and embodiment (Gard, 2003, p. 211). Azzarito and Solmon (2009) argue that to explore and recognize the continuum of muscularity, aggression, skills, and body size may contribute to opening up the activities so that they are inclusive of all pupils. In this way, the authors claim that physical education can create opportunities to develop lifelong meaningful physicality (p.189). 
Exploring (new) movement activities may help pupils to value physical activity, by providing them with opportunities to become skilled and motivated about participation in physical activity both in physical education and outside school (Hill, 2015, p. 775). Several studies highlight that connections between physical education and lifelong activity depend on whether the pupils find the activities meaningful (Hill, 2015; Lambert, 2018; O’Connor, 2018). Movement narratives aligned to experiences of the 'first rush of movement' ${ }^{3}$ can help pupils to develop an awareness of what is meaningful to them. Through the priority given to bodily understandings of movement as a felt, sensory experience, participants were able to express meaning across a wide range of movement contexts (O'Connor, 2018, p. 14). The teacher can use these embodied meaning-making stories as a potential springboard for further exploration and activity in physical education, by letting such stories influence the choice of activities in physical education classes (O’Connor, 2018, p. 11). Embodied learning is sensory in nature, as the participants pay cognitive, physical, and social attention to their environment while moving (Lambert, 2018, p. 720). Activities with purpose and intentionality activate and engage pupils, and Lambert (2018) encourages teachers to look outside the subject of physical education for inspiration, using the fire-fighting camps she visited for her sensory ethnographic work as an example (p. 733).

To summarize this theme, exploring (new) movement is a central aspect of pedagogies of embodiment. Exploring their own capability may give pupils' opportunities to reflect upon how the concepts of ability and skills may be understood. The research presented highlights that pupils experience some activities as gendered.

\footnotetext{
${ }^{3}$ The first rush of movement is described phenomenologically as experiences like "childhood vitality, playfulness, exuberance, spontaneity, and delight” (Smith, 2007, p. 51).
} 
Movement exploration may therefore be used to achieve goals like challenging stereotypical understandings of gender and ability. As such, there is a certain relationship to the first theme we presented, enabling critical reflections: by exploring new and - for the pupils - unusual ways of moving, they may come to see their own taken for granted ideas about what constitutes ability and the value activities. While this research is drawing on theoretical resources from Bourdieu, the exploring-aspect of this theme is supported by theoretical insights from phenomenology and phenomenography. The latter approaches emphasize the subjectively felt experience of moving and is thus particularly suited to guide researchers and teachers in planning and investigating the 'what it is like' character of movement activities. As such, exploring the meaning and experience of physical activity may encourage pupils to value physical activity.

\section{Concluding discussion}

The studies included in this review have a variety of theoretical foundations, and offer diverse perspectives on the concept of embodiment. Most of the studies that focus on enabling critical reflection are positioned theoretically within feminist theories, specifically within third wave feminism focusing on gender and diversity, and Foucaultinspired post structural feminism. Within these studies students' 'embodied experiences' are often understood as a result of societal influence, i.e. that different discourses of health and beauty have strong impact on students' embodied experiences. Consequently, these studies prescriptions for pedagogies of embodiment are to challenge and critique discourses and practices that are unhealthy and limiting for students' movement experiences. In contrast, the studies that focus on exploring new movements are more often positioned within phenomenology or use Bourdieu's theoretical concepts. In these studies, embodied experiences are understood as lived experience and more often studied "from within", focusing on experience as a 
phenomenon in its own right that cannot be reduced, a priori, to any discourses or other "social facts". Consequently, these studies' recommendations are to facilitate pedagogies of embodiment by letting students explore their own capability and reflect on their embodied experience of different activities. This finding underlines Shilling's statement about a 'theoretical cleavage' (2010, p. 164 ) between more Foucauldianinspired analyses and more phenomenological approaches to embodied experiences. At the same, the studies seem to have in common the understanding of the body as something pupils are. Pedagogies of embodiment take into account the irreducible relationship among teachers, learners, and subject matter (Quennerstedt, 2019). In this review, the aim has been to explore empirical research on pedagogies of embodiment in physical education. In order to do so, we searched for, and analyzed, studies that revolve around pupils' embodied experiences in physical education. The results show that pedagogies of embodiment centre on enabling critical reflection about hegemonic notions of health, gender, and body ideals, and exploring (new) movements.

A common characteristic of the studies included is the application of an inductive and pupil-centered approach to teaching. In giving pupils the opportunity to explore (new) movements, the teacher is being more of a facilitator than an instructor. Through pupils' own exploration of movement and reflection on their embodied experiences of different ways of moving, pupils can discover how they experience (new) activities and reflect on their own learning processes. An example of this is Bergentoft's study (2018), in which running is used as a way to increase body awareness. By analyzing the activities' critical aspects and focusing on the learning objects instead of the activity per se, the approach facilitates the development of body awareness (Bergentoft, 2018, p. 16). 
The review also shows that teaching according to pedagogies of embodiment has implications for the relationship between teacher and pupils. Within pedagogies of embodiment, the teacher necessarily gives pupils some influence over the curriculum. The pupils' opportunity to contribute in the co-construction of the curriculum is a critical element in, for example, activist approaches. Several of the studies included suggest activist approaches as fruitful for further work facilitating embodied learning and meaningful experiences within physical education. An example of how the power relationship between teacher and pupils changes can be seen in Oliver and others' work with pupils who are disengaged in physical education. Within these studies, the focus is on helping the pupils to identify barriers to participation and subsequently co-creating a new physical education curriculum together with the pupils (Oliver \& Hamzeh, 2010; Oliver et al., 2009). Authorizing pupil voice (Cook-Sather, 2002) changes the power dynamic between the teacher and pupil, as teachers cede power to pupils, thus providing them with freedom and co-responsibility for their own learning process. In this way, pupils are not only developing critical thinking skills, but the empowerment may also be felt as the pupils contribute to develop the subject of physical education.

The review also stresses that teaching with pedagogies of embodiment has implications for physical education content. The articles included point to the importance of setting aside time for reflection and communication together with the pupils before, during, and after activities. This involves reflection on both selection of content and on how embodied learning is experienced. Conversations about what constitutes good health, ability, and gender equity can stimulate pupils' reflection and challenge what they take for granted. Such reflection and challenge can also be achieved through (new) experiences of movement, which may be transgressive. Exploring (new) movements can give pupils opportunities to reconsider what is taken 
for granted, for example with regards to gender roles and ability. An example of this is the study by Evans et al. (2015) of able-bodied pupils' experiences with wheelchair basketball. Exploring disability sport may challenge non-disabled pupils' ideas of what ability ('to be able') means.

There is no exact recipe for implementing pedagogies of embodiment that will fit all pupils and groups, but we hope that this review inspires teachers to rethink physical education in line with the given examples. Implementing pedagogies of embodiment may include aspects from both main themes in this review: investigating pupils' experiences by listening to them, facilitating the students' critical reflection to have practical implications by including them in co-constructing the curriculum, and facilitate a broad specter of movement experiences and reflection about normativity, ability and meaningfulness.

Future research should investigate further the possibilities pedagogies of embodiment gives for teachers and learners: when learning to move and moving to learn. As we noted earlier in this paper, pedagogies of embodiment's potential to challenge traditional pedagogy (Fitzpatrick \& McGlashan, 2017; Kirk, 2020; Standal, 2015) may be further explored, in order to "render physical education inclusive, fair, and equitable as an embodied experience for young people" (Kirk, 2020, p. 105). The reviewed literature have advanced research in physical education by extending the knowledge about alternative pedagogies in physical education. What characterizes the diverse range of work on pedagogies of embodiment is that it contributes to develop physical education's social justice agenda.

In conclusion, we want to point out that a common aim for pedagogies of embodiment is to minimize the harm that negative experiences in physical education can have for pupils, especially pupils from groups that are considered vulnerable for 
exclusion from the subject. As an alternative, pedagogies of embodiment aim to create an inclusive, fair, equitable and empowering school subject. Taken together, the studies included argue that enabling critical reflection and exploration of (new) activities may improve pupils' experiences and positive identity work in physical education. Through critical reflection, pupils are given the opportunity to reflect for themselves, develop resistance to unhealthy practices, and make up their own opinions and choices and try these in practice. Critical reflection skills may also help pupils in learning how to reveal the norms, values and power relations that underpins the movement culture that is present in society. Developing reflection skills is not only a cognitive process, but outcome from a practical process of participating in discussions and exploring (new) movements. Developing body awareness may help pupils to get to know themselves better, and facilitate exploration and extension of their own capacities and boundaries. Thus, they may be equipped to take action for creating a subject they find enjoyable and meaningful. By uniting critical thinking and body awareness, pedagogies of embodiment strive for pupils to experience homelike feelings when moving and participating in physical education.

\section{References}

Aggerholm, K., Standal, O., Barker, D. M., \& Larsson, H. (2018). On practising in physical education: outline for a pedagogical model. Physical Education and Sport Pedagogy, 23(2), 197-208. doi:10.1080/17408989.2017.1372408

Armour, K. M. (1999). The case for a body- focus in education and physical education. Sport, Education and Society, 4(1), 5-15.

Arnold, P. J. (1979). Meaning in movement, sport and phyisal education. London, UK: Heinemann.

Azzarito, L., \& Hill, J. (2013). Girls looking for a 'second home': bodies, difference and places of inclusion. Physical Education \& Sport Pedagogy, 18(4), 351-375.

Azzarito, L., Simon, M., \& Marttinen, R. (2016). "Stop photoshopping!": A visual participatory inquiry into students' responses to a body curriculum. Journal of Teaching in Physical Education, 35(1), 54-69. doi:10.1123/jtpe.2014-0166

Azzarito, L., \& Solmon, M. (2009). An Investigation of Students' Embodied Discourses in Physical Education: A Gender Project. Journal of Teaching in Physical Education, 28(2), 173-191. 
Bailey, R., \& Pickard, A. (2010). Body learning: examining the processes of skill learning in dance. Sport, Education \& Society, 15(3), 367-382.

Benn, T., Dagkas, S., \& Jawad, H. (2011). Embodied faith: Islam, religious freedom and educational practices in physical education. Sport, Education \& Society, 16(1), 17-34.

Bergentoft, H. (2018). Running: A way to increase body awareness in secondary school physical education. European Physical Education Review. doi:10.1177/1356336X18814035

Braun, V., \& Clarke, V. (2006). Using thematic analysis in psychology. Qualitative Research in Psychology, 3(2), 77-101. doi:10.1191/1478088706qp063oa

Brown, T. D., \& Payne, P. G. (2009). Conceptualizing the phenomenology of movement in physical education: Implications for pedagogical inquiry and development. Quest, 61, 418-441.

Cheville, J. (2005). Confronting the problem of embodiment. International Journal of Qualitative Studies in Education, 18(1), 85-107. doi:10.1080/09518390412331318405

Connolly, M. (1995). Phenomenology, physical education, and special populations. Human Studies, 18, 25-40. doi:10.1007/BF01322838

Cook-Sather, A. (2002). Authorizing Students' Perspectives: Toward Trust, Dialogue, and Change in Education. 31(4), 3-14. doi:10.3102/0013189x031004003

Dagkas, S., \& Hunter, L. (2015). 'Racialised' pedagogic practices influencing young Muslims' physical culture. Physical Education \& Sport Pedagogy, 20(5), 547558.

Depper, A., Fullagar, S., \& Francombe-Webb, J. (2019). This Girl Can? The Limitations of Digital Do-It-Yourself Empowerment in Women's Active Embodiment Campaigns. In D. Parry, C. Johnson, \& S. Fullagar (Eds.), Digital Dilemmas (pp. 183-204). Cham: Palgrave Macmillan.

Enright, E., \& O'Sullivan, M. (2012). Physical Education "in All Sorts of Corners:" Student Activists Transgressing Formal Physical Education Curricular Boundaries. Research Quarterly for Exercise and Sport, 82(2), 255-267.

Enright, E., \& O'Sullivan, M. (2010). 'Can I do it in my pyjamas?' Negotiating a physical education curriculum with teenage girls. European Physical Education Review, 16(3), 203-222.

Evans, A. B., Bright, J. L., \& Brown, L. J. (2015). Non-disabled secondary school children's lived experiences of a wheelchair basketball programme delivered in the East of England. Sport, Education \& Society, 20(6), 741-761.

Fisette, J. L. (2011). Exploring how girls navigate their embodied identities in physical education. Physical Education \& Sport Pedagogy, 16(2), 179-196.

Fisette, J. L., \& Walton, T. A. (2014). 'If You Really Knew Me' ... I am empowered through action. Sport, Education \& Society, 19(2), 131-152.

Fisette, J. L., \& Walton, T. A. (2015). "Beautiful You": Creating Contexts for Students to Become Agents of Social Change. Journal of Educational Research, 108(1), 62-76.

Fitzgerald, H. (2005). Still feeling like a spare piece of luggage? Embodied experiences of (dis)ability in physical education and school sport. Physical Education \& Sport Pedagogy, 10(1), 41-59.

Fitzpatrick, K., \& McGlashan, H. (2017). Rethinking straight pedagogy: Gender, sexuality and physical education. In L. Randall \& D. B. Robinson (Eds.), Social Justice in Physical Education: Critical reflections and pedagogy for change (pp. 102121). Toronto: Canadian Scholars Press. 
Francombe-Webb, J., \& Toffoletti, K. (2018). Sporting Females: Power, Diversity and the Body. In L. Mansfield, J. Caudwell, B. Wheaton, \& B. Watson (Eds.), The Palgrave Handbook of Feminism and Sport, Leisure and Physical Education (pp. 43-55). London: Palgrave Macmillan.

Gard, M. (2003). Being Someone Else: Using Dance in Anti-Oppressive Teaching. Educational Review, 55(2), 211-223.

Garrett, R. (2004). Negotiating a physical identity: girls, bodies and physical education. Sport, Education \& Society, 9(2), 223-237.

Gorely, T., Holroyd, R., \& Kirk, D. (2003). Muscularity, the Habitus and the Social Construction of Gender: Towards a gender-relevant physical education. British Journal of Sociology of Education, 24(4), 429-448. doi:10.1080/01425690301923

Grant, M. J., \& Booth, A. (2009). A typology of reviews: an analysis of 14 review types and associated methodologies. Health Information and Libraries Journal, 26, 91-108.

Hill, J. (2015). 'If you miss the ball, you look like a total muppet!' Boys investing in their bodies in physical education and sport. Sport, Education and Society, 20(6), 762-779. doi:10.1080/13573322.2013.820695

Hill, J., \& Azzarito, L. (2012). Representing valued bodies in PE: A visual inquiry with British Asian girls. Physical Education and Sport Pedagogy, 17(3), 263-276. doi:10.1080/17408989.2012.690381

Hills, L. (2007). Friendship, physicality, and physical education: an exploration of the social and embodied dynamics of girls' physical education experiences. Sport, Education \& Society, 12(3), 335-354.

Kirk, D. (2010). Physical Education Futures. London: Routledge.

Kirk, D. (2020). Precarity, Critical Pedagogy and Physical Education. Oxon: Routledge.

Kirk, D., \& Tinning, R. (1994). Embodied self- identity, healthy lifestyles and school physical education. Sociology of Health \& Illness, 16(5), 600-625. doi:10.1111/1467-9566.ep11348096

Lambert, K. (2018). Girls on fire: alternative movement pedagogies to promote engagement of young women in physical activity. Sport, Education and Society, 23(7), 720-735. doi:10.1080/13573322.2018.1483909

Leder, D. (1992). A tale of two bodies: The Cartesian corpse and the lived body. In D. Leder (Ed.), The Body in Medical Thought and Practice (pp. 17-36). Dordrecht, The Netherlands: Kluwer academic publishers.

Light, R. (2007). Re-examining Hegemonic Masculinity in High School Rugby: The Body, Compliance and Resistance. Quest (00336297), 59(3), 323-338.

Lindgren, R., \& Barker, D. (2019). Implementing the Movement-Oriented Practising Model (MPM) in physical education: empirical findings focusing on student learning. Physical Education and Sport Pedagogy, 24(5), 534-547. doi:10.1080/17408989.2019.1635106

lisahunter. (2004). Bourdieu and the social space of the PE class: reproduction of Doxa through practice. Sport, Education \& Society, 9(2), 175-192.

Nyberg, G. (2014). Exploring "knowings" in human movement: The practical knowledge of pole-vaulters. European Physical Education Review, 20(1), 72-89.

Nyberg, G., Barker, D., \& Larsson, H. (2020). Exploring the educational landscape of juggling - challenging notions of ability in physical education. Physical Education and Sport Pedagogy, 25(2), 201-212. doi:10.1080/17408989.2020.1712349 
Nyberg, G., \& Carlgren, I. (2015). Exploring capability to move - somatic grasping of house-hopping. Physical Education and Sport Pedagogy, 20(6), 612-628. doi:10.1080/17408989.2014.882893

Nyberg, G., \& Meckbach, J. (2017). Exergames 'as a teacher' of movement education: exploring knowing in moving when playing dance games in physical education. Physical Education and Sport Pedagogy, 22(1), 1-14. doi:10.1080/17408989.2015.1112778

O’Connor, J. (2018). Exploring a pedagogy for meaning-making in physical education. European Physical Education Review. doi:10.1177/1356336X18802286

Oliver, K., \& Hamzeh, M. (2010). "The Boys Won't Let Us Play": Fifth-grade mestizas challenge physical activity discourse at school. Research Quarterly for Exercise and Sport, 81(1), 38-51. doi:10.1080/02701367.2010.10599626

Oliver, K., Hamzeh, M., \& McCaughtry, N. (2009). Girly Girls Can Play Games / Las Niñas Pueden Jugar Tambien: Co-Creating a Curriculum of Possibilities With Fifth-Grade Girls. Journal of Teaching in Physical Education, 28(1), 90-110.

Oliver, K., \& Kirk, D. (2015). Girls, Gender and Physical Education. London: Routledge.

Oliver, K., \& Kirk, D. (2016). Transformative pedagogies for challenging body culture in physical education. In C. D. Ennis (Ed.), Routledge handbook of physical education pedagogies (pp. 307-318). London, UK: Routledge.

Oliver, K., \& Lalik, R. (2001). The body as curriculum: Learning with adolescent girls. Journal of Curriculum Studies, 33(3), 303-333. doi:10.1080/00220270010006046

Oliver, K., \& Lalik, R. (2004a). 'The Beauty Walk, this ain't my topic': learning about critical inquiry with adolescent girls. Journal of Curriculum Studies, 36(5), 555586. doi:10.1080/0022027032000139397

Oliver, K., \& Lalik, R. (2004b). Critical Inquiry on the Body in Girls' Physical Education Classes: A Critical Poststructural Perspective. Journal of Teaching in Physical Education, 23, 162-195.

Pronger, B. (1995). Rendering the Body. The Implicit Lessons of Gross Anatomy. Quest, 47, 427-446.

Quennerstedt, M. (2019). Physical education and the art of teaching: transformative learning and teaching in physical education and sports pedagogy. Sport, Education and Society, 24(6), 611-623. doi:10.1080/13573322.2019.1574731

Rich, E. (2018). Healthism, Girls' Embodiment, and Contemporary Health and Physical Education: From Weight Management to Digital Practices of Optimization. In L. Mansfield, J. Caudwell, B. Wheaton, \& B. Watson (Eds.), The Palgrave Handbook of Feminism and Sport, Leisure and Physical Education (pp. 523536). London: Palgrave Macmillan.

Shilling, C. (2010). Exploring the society-body-school nexus: theoretical and methodology issues in the study of body pedagogics. Sport, Education and Society, 15(2), 151-167. doi:10.1080/13573321003683786

Smith, S. J. (2007). The First Rush of Movement: A Phenomenological Preface to Movement Education. Phenomenology \& Practice, 1(1), 47-75.

Standal, Ø. F. (2015). Phenomenology and pedagogy in physical education. Abingdon: Routledge.

Standal, Ø. F. (2020). Embodiment: philosophical considerations of the body in adaptive physical education. In S. R. Hodge, J. A. Haegele, \& D. R. Shapiro (Eds.), Routledge Handbook of Adapted Physical Education (pp. 227-238). New York, NY: Routledge. 
Standal, Ø. F., \& Aggerholm, K. (2016). Habits, skills and embodied experiences: a contribution to philosophy of physical education. Sport, Ethics and Philosophy, 10(3), 269-282. doi:10.1080/17511321.2016.1220972

Stolz, S. A. (2015). Embodied Learning. Educational Philosophy and Theory, 47(5), 474-487. doi:10.1080/00131857.2013.879694

Stride, A. (2016). Centralising space: the physical education and physical activity experiences of South Asian, Muslim girls. Sport, Education and Society, 21(5), 677-697.

Tinning, R. (2010). Pedagogy and human movement. Theory, practice, research. London, UK: Routledge.

Tischler, A., \& McCaughtry, N. (2011). PE Is Not for Me: When Boys' Masculinities Are Threatened. Research Quarterly for Exercise \& Sport, 82(1), 37-48.

Whitehead, M. (1990). Meaningful existence, embodiment and physical education. Journal of Philosophy of Education, 24(1), 3-14.

Windram-Geddes, M. (2013). Fearing fatness and feeling fat: Encountering affective spaces ofphysical activity. Emotion, Space and Society, 9(1), 42-49.

doi:10.1016/j.emospa.2013.06.006

Wright, J. (2000). Bodies, Meanings and Movement: A Comparison of the Language of a Physical Education Lesson and a Feldenkrais Movement Class. Sport, Education \& Society, 5(1), 35-49.

\begin{tabular}{|c|c|c|c|c|c|c|c|}
\hline \multicolumn{8}{|c|}{ Appendix: Included Articles } \\
\hline Author & Year & Title & Journal & $\begin{array}{l}\text { First author's } \\
\text { country of } \\
\text { employment }\end{array}$ & $\begin{array}{l}\text { Purpose/ aim of } \\
\text { study }\end{array}$ & $\begin{array}{l}\text { Theoretical } \\
\text { perspectives } \\
\text { referred to }\end{array}$ & Findings \\
\hline $\begin{array}{l}\text { Azzarito \& } \\
\text { Hill }\end{array}$ & 2013 & $\begin{array}{l}\text { Girls looking for a } \\
\text { 'second home': } \\
\text { bodies, difference } \\
\text { and places of } \\
\text { inclusion }\end{array}$ & $\begin{array}{l}\text { Physical } \\
\text { Education } \\
\text { and Sport } \\
\text { Pedagogy }\end{array}$ & The U.K. & $\begin{array}{l}\text { Further } \\
\text { understandings of } \\
\text { Ethnic-minority } \\
\text { girls' emplaced } \\
\text { embodiment by } \\
\text { investigating the } \\
\text { link between girls' } \\
\text { physicality and their } \\
\text { views of physical } \\
\text { activity spaces in } \\
\text { their communities. }\end{array}$ & Feminism & $\begin{array}{l}\text { The girls' active body-selves tend to t } \\
\text { shape in spaces 'like home' that were } \\
\text { 'social,' friend-, and family-oriented, } \\
\text { also intimate and shielded spaces whe } \\
\text { could invent themselves and craft thei } \\
\text { bodies in sport-oriented, virtual landsc }\end{array}$ \\
\hline $\begin{array}{l}\text { Azzarito, } \\
\text { Simon \& } \\
\text { Marttinen }\end{array}$ & 2016 & $\begin{array}{l}\text { "Stop } \\
\text { Photoshopping!": } \\
\text { A Visual } \\
\text { Participatory } \\
\text { Inquiry Into } \\
\text { Students" } \\
\text { Responses to a } \\
\text { Body Curriculum }\end{array}$ & $\begin{array}{l}\text { Journal of } \\
\text { Teaching in } \\
\text { Physical } \\
\text { Education }\end{array}$ & The USA & $\begin{array}{l}\text { Explore the extent to } \\
\text { which the creation } \\
\text { and implementation } \\
\text { of a Body } \\
\text { Curriculum into a } \\
\text { fitness unit in a } \\
\text { secondary school } \\
\text { enhanced students' } \\
\text { critical embodied } \\
\text { learning. }\end{array}$ & $\begin{array}{l}\text { Shilling (2006) } \\
\text { Third-wave } \\
\text { feminism }\end{array}$ & $\begin{array}{l}\text { Participants rejected media narratives } \\
\text { idealized bodies and embodied more } \\
\text { "realistic" ideals about the body. Thei } \\
\text { to look in a certain way was still fram } \\
\text { fixed normative white standards (p.67 }\end{array}$ \\
\hline $\begin{array}{l}\text { Azzarito \& } \\
\text { Solomon }\end{array}$ & 2009 & $\begin{array}{l}\text { An Investigation } \\
\text { of Students' } \\
\text { Embodied } \\
\text { Discourses in } \\
\text { Physical } \\
\text { Education: A } \\
\text { Gender Project }\end{array}$ & $\begin{array}{l}\text { Journal of } \\
\text { Teaching in } \\
\text { Physical } \\
\text { Education }\end{array}$ & The U.K. & $\begin{array}{l}\text { Investigate the ways } \\
\text { students' } \\
\text { embodiment of } \\
\text { discursive constructs } \\
\text { differed in terms of } \\
\text { gender and race. } \\
\text { Investigate the } \\
\text { relation between } \\
\text { students' embodied } \\
\text { discursive constructs } \\
\text { and students' } \\
\text { favorite/least } \\
\text { favorite physical } \\
\text { activities in PE. }\end{array}$ & $\begin{array}{l}\text { Feminism } \\
\text { Poststructuralism }\end{array}$ & $\begin{array}{l}\text { Discursive constructs about the body } \\
\text { predicted the gendered nature of girls" } \\
\text { boys' favorite activities, and were infl } \\
\text { in producing students' choice of "genc } \\
\text { appropriate" physical activities. }\end{array}$ \\
\hline $\begin{array}{l}\text { Benn, Dagkas } \\
\text { \& Jawad }\end{array}$ & 2011 & $\begin{array}{l}\text { Embodied faith: } \\
\text { Islam, religious } \\
\text { freedom and } \\
\text { educational } \\
\text { practices in } \\
\text { physical education }\end{array}$ & $\begin{array}{l}\text { Sport, } \\
\text { Education } \\
\text { and Society }\end{array}$ & The U.K. & $\begin{array}{l}\text { Improve the } \\
\text { inclusion of Muslim } \\
\text { girls in PE and } \\
\text { school sport (in } \\
\text { Birmingham, } \\
\text { England). }\end{array}$ & Feminist theory & $\begin{array}{l}\text { Diversity in young people's preferenc } \\
\text { Islamic dress requirements: Where } \\
\text { accommodation could not be found, sc } \\
\text { people did not participate in PE. Scho } \\
\text { with more flexibility and choice in kit } \\
\text { had higher levels of participation. }\end{array}$ \\
\hline
\end{tabular}




\begin{tabular}{|c|c|c|c|c|c|c|c|}
\hline \multicolumn{8}{|c|}{ Appendix: Included Articles } \\
\hline Author & Year & Title & Journal & $\begin{array}{l}\text { First author's } \\
\text { country of } \\
\text { employment }\end{array}$ & $\begin{array}{l}\text { Purpose/ aim of } \\
\text { study }\end{array}$ & $\begin{array}{l}\text { Theoretical } \\
\text { perspectives } \\
\text { referred to }\end{array}$ & Findings \\
\hline Bergentoft & 2018 & $\begin{array}{l}\text { Running: A way } \\
\text { to increase body } \\
\text { awareness in } \\
\text { secondary school } \\
\text { physical education }\end{array}$ & $\begin{array}{l}\text { European } \\
\text { Physical } \\
\text { Education } \\
\text { Review }\end{array}$ & Sweden & $\begin{array}{l}\text { Examine how } \\
\text { students learn to } \\
\text { analyze sensations } \\
\text { and feelings while } \\
\text { running. } \\
\text { (a) What aspects of } \\
\text { the running } \\
\text { movement do } \\
\text { students discern as } \\
\text { critical for increased } \\
\text { awareness of body } \\
\text { posture in running? } \\
\text { (b) In what way do } \\
\text { lesson designs and } \\
\text { teaching techniques } \\
\text { affect students' } \\
\text { identification of } \\
\text { critical aspects of } \\
\text { body posture in } \\
\text { running? }\end{array}$ & $\begin{array}{l}\text { Body awareness } \\
\text { Embodiment } \\
\text { Phenomenology }\end{array}$ & $\begin{array}{l}\text { Students can identify critical aspects o } \\
\text { movement when they are offered } \\
\text { opportunities and space to reflect on a } \\
\text { discuss these matters, and thereby bec } \\
\text { more body aware. Discovery of critica } \\
\text { aspects can help students to grasp wha } \\
\text { individual aims they could strive for it } \\
\text { future lessons. }\end{array}$ \\
\hline $\begin{array}{l}\text { Dagkas \& } \\
\text { Hunter }\end{array}$ & 2015 & $\begin{array}{l}\text { 'Racialised' } \\
\text { pedagogic } \\
\text { practices } \\
\text { influencing young } \\
\text { Muslims' physical } \\
\text { culture }\end{array}$ & $\begin{array}{l}\text { Physical } \\
\text { Education } \\
\text { and Sport } \\
\text { Pedagogy }\end{array}$ & The U.K. & $\begin{array}{l}\text { The paper examines } \\
\text { the 'racialised' } \\
\text { pedagogic practices } \\
\text { in various fields that } \\
\text { influence young } \\
\text { Muslims' } \\
\text { dispositions to } \\
\text { physical culture. }\end{array}$ & $\begin{array}{l}\text { Bourdieu: the } \\
\text { intersectionality } \\
\text { of various fields } \\
\text { (family, } \\
\text { religion and } \\
\text { school) }\end{array}$ & $\begin{array}{l}\text { Religion had limited influence on the } \\
\text { participants' agency when intersecting } \\
\text { schooling and social class with regard } \\
\text { embodiment of active physical culture } \\
\text { Economic capital had a considerable } \\
\text { influence on participants' physical cul } \\
\text { it contributed to young people's acces } \\
\text { opportunities, agency and body pedag } \\
\text { The school play a significant role in } \\
\text { influencing and enabling young } \\
\text { Muslims' physical culture. }\end{array}$ \\
\hline $\begin{array}{l}\text { Enright \& } \\
\text { O'Sullivan }\end{array}$ & 2010 & $\begin{array}{l}\text { 'Can I do it in my } \\
\text { pyjamas?' } \\
\text { Negotiating a } \\
\text { physical education } \\
\text { curriculum with } \\
\text { teenage girls }\end{array}$ & $\begin{array}{l}\text { European } \\
\text { Physical } \\
\text { Education } \\
\text { Review }\end{array}$ & Ireland & $\begin{array}{l}\text { How does increased } \\
\text { involvement in } \\
\text { curricular decision- } \\
\text { making impact on } \\
\text { the girls, } \\
\text { engagement with } \\
\text { their PE curriculum? } \\
\text { (p.205) }\end{array}$ & $\begin{array}{l}\text { Participatory } \\
\text { action research } \\
\text { (PAR) } \\
\text { Gordon (2006) }\end{array}$ & $\begin{array}{l}\text { The negotiated curricula facilitated the } \\
\text { in connecting PE to the sociocultural } \\
\text { contexts of their lives and opened up } \\
\text { opportunities for students to critically } \\
\text { appraise their previous experiences of } \\
\text { relation to their lives, backgrounds an } \\
\text { values while engaging them in conside } \\
\text { the possibilities for PE. The girls then } \\
\text { actively participated in constructing } \\
\text { knowledge and action that connected t } \\
\text { PE curriculum to their everyday lives } \\
\text { (p.218). }\end{array}$ \\
\hline $\begin{array}{l}\text { Enright \& } \\
\text { O'Sullivan }\end{array}$ & 2012 & $\begin{array}{l}\text { Physical } \\
\text { education 'in all } \\
\text { sorts of corners': } \\
\text { Student activists } \\
\text { transgressing } \\
\text { formal physical } \\
\text { education } \\
\text { curricular } \\
\text { boundaries }\end{array}$ & $\begin{array}{l}\text { Research } \\
\text { Quarterly } \\
\text { for } \\
\text { Exercise } \\
\text { and Sport }\end{array}$ & Ireland & $\begin{array}{l}\text { What happens when } \\
\text { scholars engage with } \\
\text { students to challenge } \\
\text { formal physical } \\
\text { education curricular } \\
\text { boundaries and } \\
\text { connect with } \\
\text { students' physical } \\
\text { culture? What are } \\
\text { the benefits and the } \\
\text { challenges } \\
\text { associated with } \\
\text { engaging in this sort } \\
\text { of practical } \\
\text { activism? (p.256) }\end{array}$ & $\begin{array}{l}\text { Participatory } \\
\text { action research } \\
\text { (PAR) } \\
\text { Gordon (2006) }\end{array}$ & $\begin{array}{l}\text { A boundary-crossing approach to phy } \\
\text { education can facilitate students in fin } \\
\text { their own meanings in physical educat } \\
\text { and physical activity. Supporting bour } \\
\text { crossing practices is a time- and thoug } \\
\text { intensive pedagogical design that will } \\
\text { challenging for many physical educati } \\
\text { teachers (p.255). }\end{array}$ \\
\hline $\begin{array}{l}\text { Evans, Bright } \\
\text { \& Brown }\end{array}$ & 2015 & $\begin{array}{l}\text { Non-disabled } \\
\text { secondary school } \\
\text { children's lived } \\
\text { experiences of a } \\
\text { wheelchair } \\
\text { basketball } \\
\text { programme } \\
\text { delivered in the } \\
\text { East of England }\end{array}$ & $\begin{array}{l}\text { Sport, } \\
\text { Education } \\
\text { and Society }\end{array}$ & The U.K. & $\begin{array}{l}\text { Investigate the } \\
\text { embodied } \\
\text { experiences of non- } \\
\text { disabled secondary } \\
\text { school pupils during } \\
\text { a program designed } \\
\text { to introduce } \\
\text { disability sport to } \\
\text { non-disabled } \\
\text { schoolchildren } \\
\text { entitled 'The } \\
\text { Wheelchair Sports } \\
\text { Project'. }\end{array}$ & Bourdieu & $\begin{array}{l}\text { Due to their own embodied experienc } \\
\text { pupils began to question their percepti } \\
\text { the potential ability of participants wit } \\
\text { physical impairments. Pupils describe } \\
\text { physical demands of wheelchair baske } \\
\text { and began to focus upon similarities b } \\
\text { themselves and physically disabled } \\
\text { individuals. }\end{array}$ \\
\hline
\end{tabular}




\begin{tabular}{|c|c|c|c|c|c|c|c|}
\hline \multicolumn{8}{|c|}{ Appendix: Included Articles } \\
\hline Author & Year & Title & Journal & $\begin{array}{l}\text { First author's } \\
\text { country of } \\
\text { employment }\end{array}$ & $\begin{array}{l}\text { Purpose/ aim of } \\
\text { study }\end{array}$ & $\begin{array}{l}\text { Theoretical } \\
\text { perspectives } \\
\text { referred to }\end{array}$ & Findings \\
\hline & & & & & $\begin{array}{l}\text { The impact of the } \\
\text { project on pupils' } \\
\text { perceptions of } \\
\text { physical disability } \\
\text { was investigated. }\end{array}$ & & \\
\hline Fisette & 2011 & $\begin{array}{l}\text { Exploring how } \\
\text { girls navigate their } \\
\text { embodied } \\
\text { identities in } \\
\text { physical education }\end{array}$ & $\begin{array}{l}\text { Physical } \\
\text { Education } \\
\text { and Sport } \\
\text { Pedagogy }\end{array}$ & The USA & $\begin{array}{l}\text { Explore how } \\
\text { adolescent girls } \\
\text { articulate their } \\
\text { embodiment and } \\
\text { navigate their } \\
\text { embodied identities } \\
\text { within the public } \\
\text { and private physical } \\
\text { education context. }\end{array}$ & $\begin{array}{l}\text { Social } \\
\text { constructionism } \\
\text { Foucault }\end{array}$ & $\begin{array}{l}\text { Participants' embodied identities in P } \\
\text { focused primarily on the socially cons } \\
\text { idealized female body. } \\
\text { Based on participants' own sense of s } \\
\text { concern about how others may survey } \\
\text { judge them, they created strategies } \\
\text { (individually and collaboratively) to f } \\
\text { comfortable, safe, and trusting of othe } \\
\text { within the PE environment. }\end{array}$ \\
\hline $\begin{array}{l}\text { Fisette \& } \\
\text { Walton }\end{array}$ & 2014 & $\begin{array}{l}\text { 'If You Really } \\
\text { Knew Me'... I } \\
\text { am empowered } \\
\text { through action }\end{array}$ & $\begin{array}{l}\text { Sport, } \\
\text { Education } \\
\text { and Society }\end{array}$ & The USA & $\begin{array}{l}\text { Engage high school } \\
\text { girls in collaborative } \\
\text { activist research to } \\
\text { explore how they } \\
\text { made meaning of } \\
\text { their mediated } \\
\text { identities, how they } \\
\text { translated these } \\
\text { identities to their } \\
\text { embodied sense of } \\
\text { self and how that } \\
\text { influenced their } \\
\text { schooling } \\
\text { experiences. }\end{array}$ & $\begin{array}{l}\text { Activist research } \\
\text { Feminism }\end{array}$ & $\begin{array}{l}\text { Discourse on media consumption: use } \\
\text { media to escape their problems, medi } \\
\text { changed their behavior and perspectiv } \\
\text { The girls indicated that they felt a sen } \\
\text { empowerment by taking social action }\end{array}$ \\
\hline $\begin{array}{l}\text { Fisette \& } \\
\text { Walton }\end{array}$ & 2015 & $\begin{array}{l}\text { "Beautiful You": } \\
\text { Creating Contexts } \\
\text { for Students to } \\
\text { Become Agents of } \\
\text { Social Change }\end{array}$ & $\begin{array}{l}\text { The Journal } \\
\text { of } \\
\text { Educational } \\
\text { Research }\end{array}$ & The USA & $\begin{array}{l}\text { Explore how high } \\
\text { school girls' } \\
\text { mediated and } \\
\text { embodied identities } \\
\text { were translated. } \\
\text { Address how the } \\
\text { girls (a) perceive } \\
\text { and articulate their } \\
\text { embodied identities, } \\
\text { (b) navigate the } \\
\text { social barriers they } \\
\text { encountered within } \\
\text { the structured } \\
\text { institution of the } \\
\text { school, and (c) } \\
\text { might be able to } \\
\text { create their own } \\
\text { activist practice as } \\
\text { part of their learning } \\
\text { process. }\end{array}$ & $\begin{array}{l}\text { Activist research } \\
\text { Feminism }\end{array}$ & $\begin{array}{l}\text { The girls articulated and demonstratec } \\
\text { their sense of self and embodied ident } \\
\text { were translated. However, they perpet } \\
\text { and reinforced the dominant ideologie } \\
\text { girls began to translate their embodiec } \\
\text { identities, being agents of change. }\end{array}$ \\
\hline Fitzgerald & 2005 & $\begin{array}{l}\text { Still feeling like a } \\
\text { spare piece of } \\
\text { luggage? } \\
\text { Embodied } \\
\text { experiences of } \\
\text { (dis)ability in } \\
\text { physical education } \\
\text { and school sport }\end{array}$ & $\begin{array}{l}\text { Physical } \\
\text { Education } \\
\text { and Sport } \\
\text { Pedagogy }\end{array}$ & The U.K. & $\begin{array}{l}\text { Explore the nature } \\
\text { of young disabled } \\
\text { people's physical } \\
\text { education and } \\
\text { school sport } \\
\text { experiences. }\end{array}$ & Bourdieu & $\begin{array}{l}\text { A paradigm of normativity prevails in } \\
\text { PE habitus is manifest through concep } \\
\text { of ability: mesomorphic ideal, mascul } \\
\text { and high levels of motoric competenc } \\
\text { valued. }\end{array}$ \\
\hline Gard & 2003 & $\begin{array}{l}\text { Being Someone } \\
\text { Else: Using dance } \\
\text { in anti-oppressive } \\
\text { Teaching }\end{array}$ & $\begin{array}{l}\text { Educational } \\
\text { Review }\end{array}$ & Australia & $\begin{array}{l}\text { Explore the } \\
\text { possibility of using } \\
\text { physical movement, } \\
\text { particularly dance, } \\
\text { to contribute to anti- } \\
\text { oppressive } \\
\text { pedagogies in the } \\
\text { PE classroom } \\
\text { (p.211). }\end{array}$ & $\begin{array}{l}\text { Sociology of the } \\
\text { body } \\
\text { Masculinity } \\
\text { studies }\end{array}$ & $\begin{array}{l}\text { Dance movement is likely to be (at le } \\
\text { initially) an uncomfortable experience } \\
\text { some students (...); much of this disc } \\
\text { will be related to the gendered identit } \\
\text { these students. Male students use wor } \\
\text { 'weird', 'stupid' and 'dumb' to descri } \\
\text { dance movement. The association of } \\
\text { per se and particular forms of dance } \\
\text { movement with both feminine and no } \\
\text { heterosexual ways of moving and bei } \\
\text { remains strong. }\end{array}$ \\
\hline Garrett & 2004 & $\begin{array}{l}\text { Negotiating a } \\
\text { physical identity: } \\
\text { girls, bodies and } \\
\text { physical education }\end{array}$ & $\begin{array}{l}\text { Sport, } \\
\text { Education } \\
\text { and Society }\end{array}$ & Australia & $\begin{array}{l}\text { Investigates the } \\
\text { construction of a } \\
\text { physical identity } \\
\text { within PE. Explores }\end{array}$ & $\begin{array}{l}\text { Feminist } \\
\text { poststructuralist } \\
\text { methodology }\end{array}$ & $\begin{array}{l}\text { PE as sport: positive and negative } \\
\text { experiences: display physical compet } \\
\text { vs. alienation and limitation. } \\
\text { Femininity: a good body was importa }\end{array}$ \\
\hline
\end{tabular}




\begin{tabular}{|c|c|c|c|c|c|c|c|}
\hline \multicolumn{8}{|c|}{ Appendix: Included Articles } \\
\hline Author & Year & Title & Journal & $\begin{array}{l}\text { First author's } \\
\text { country of } \\
\text { employment }\end{array}$ & $\begin{array}{l}\text { Purpose/ aim of } \\
\text { study }\end{array}$ & $\begin{array}{l}\text { Theoretical } \\
\text { perspectives } \\
\text { referred to }\end{array}$ & Findings \\
\hline & & & & & $\begin{array}{l}\text { the power of } \\
\text { discourses around } \\
\text { the body and gender } \\
\text { as well as 'lived' } \\
\text { physical experiences } \\
\text { in shaping } \\
\text { subjectivities. } \\
\text { Locating discourses } \\
\text { and social practices } \\
\text { as well as structural } \\
\text { and institutional } \\
\text { factors that } \\
\text { empower or alienate } \\
\text { young women in } \\
\text { their engagement } \\
\text { within a physical } \\
\text { culture. }\end{array}$ & & $\begin{array}{l}\text { PE as a setting for friendship and hum } \\
\text { Lack of perceived physical competenc } \\
\text { significant to ongoing physical engage }\end{array}$ \\
\hline $\begin{array}{l}\text { Gorely, } \\
\text { Holroyd \& } \\
\text { Kirk }\end{array}$ & 2003 & $\begin{array}{l}\text { Muscularity, the } \\
\text { Habitus and the } \\
\text { Social } \\
\text { Construction of } \\
\text { Gender: Towards } \\
\text { a gender-relevant } \\
\text { physical education }\end{array}$ & $\begin{array}{l}\text { British } \\
\text { Journal of } \\
\text { Sociology } \\
\text { of } \\
\text { Education }\end{array}$ & The U.K. & $\begin{array}{l}\text { Develop the concept } \\
\text { of gender-relevant } \\
\text { physical education. }\end{array}$ & Bourdieu & $\begin{array}{l}\text { While the physical capital provided by } \\
\text { engagement with physical activities st } \\
\text { sport has exchange value for boys, the } \\
\text { of physical capital for girls largely ren } \\
\text { bounded within the physical activity fi } \\
\text { itself. }\end{array}$ \\
\hline Hill & 2015 & $\begin{array}{l}\text { 'If you miss the } \\
\text { ball, you look like } \\
\text { a total muppet!' } \\
\text { Boys investing in } \\
\text { their bodies in } \\
\text { physical education } \\
\text { and sport }\end{array}$ & $\begin{array}{l}\text { Sport, } \\
\text { Education } \\
\text { and Society }\end{array}$ & The U.K. & $\begin{array}{l}\text { Enquire how boys } \\
\text { negotiate the } \\
\text { connections between } \\
\text { masculinity, } \\
\text { muscularity and } \\
\text { physical/social } \\
\text { status in PE and } \\
\text { recreational sport } \\
\text { experiences. }\end{array}$ & $\begin{array}{l}\text { Bourdieu: habitus, } \\
\text { capital and field } \\
\text { Intersectionality } \\
\text { of gender and } \\
\text { ethnicity in PE }\end{array}$ & $\begin{array}{l}\text { Each of the three boys showed that at } \\
\text { they engaged in physical activity in w } \\
\text { specifically intended to work on the b } \\
\text { increase their physical capital within t } \\
\text { field of their PE class improving fitn } \\
\text { muscularity, skills or body size. } \\
\text { For these boys, decisions about when } \\
\text { how to engage in physical activity we } \\
\text { complex. They worked on their bodies } \\
\text { become or remain competent, strong o } \\
\text { performing or practicing that which w } \\
\text { gain them capital. }\end{array}$ \\
\hline $\begin{array}{l}\text { Hill \& } \\
\text { Azzarito }\end{array}$ & 2012 & $\begin{array}{l}\text { Representing } \\
\text { valued bodies in } \\
\text { PE: a visual } \\
\text { inquiry with } \\
\text { British Asian girls }\end{array}$ & $\begin{array}{l}\text { Physical } \\
\text { Education } \\
\text { and Sport } \\
\text { Pedagogy }\end{array}$ & The U.K. & $\begin{array}{l}\text { Explore varying } \\
\text { ways British Asian } \\
\text { girls visualize and } \\
\text { make sense of } \\
\text { themselves as active } \\
\text { or sporting bodies, } \\
\text { and what this means } \\
\text { for their } \\
\text { (dis)engagement in } \\
\text { physical activity. }\end{array}$ & $\begin{array}{l}\text { Feminist } \\
\text { poststructuralist } \\
\text { approach }\end{array}$ & $\begin{array}{l}\text { Many girls placed their physical activi } \\
\text { significantly in school, and saw sporti } \\
\text { bodies as male and elite. } \\
\text { Girls were physically active outside of } \\
\text { school despite not seeing themselves a } \\
\text { sporty. }\end{array}$ \\
\hline Hills & 2007 & $\begin{array}{l}\text { Friendship, } \\
\text { physicality, and } \\
\text { physical } \\
\text { education: an } \\
\text { exploration of the } \\
\text { social and } \\
\text { embodied } \\
\text { dynamics of girls' } \\
\text { physical education } \\
\text { experiences }\end{array}$ & $\begin{array}{l}\text { Sport, } \\
\text { Education } \\
\text { and Society }\end{array}$ & The U.K. & $\begin{array}{l}\text { Study girls' } \\
\text { understandings of } \\
\text { physicality and } \\
\text { power relations } \\
\text { between girls within } \\
\text { the context of } \\
\text { physical education } \\
\text { and in relation to } \\
\text { their discourses and } \\
\text { practices around } \\
\text { friendship and social } \\
\text { relationships. }\end{array}$ & Bourdieu & $\begin{array}{l}\text { (In)Competence is on display: The } \\
\text { construction of physical capital relatec } \\
\text { closely to the capacity for successful } \\
\text { displays of competence. } \\
\text { A hierarchy of competence and social } \\
\text { reveal differences: Skilled/popular gir } \\
\text { dominated activities, determined posit } \\
\text { and excluded other girls. } \\
\text { Friendship provided an alternate sourc } \\
\text { capital: that could ameliorate the } \\
\text { marginalisation of unskilled girls or re } \\
\text { the participation of skilled girls with l } \\
\text { social status. }\end{array}$ \\
\hline $\begin{array}{l}\text { Joy \& } \\
\text { Larsson }\end{array}$ & 2019 & $\begin{array}{l}\text { Unspoken: } \\
\text { exploring the } \\
\text { constitution of } \\
\text { masculinities in } \\
\text { Swedish physical } \\
\text { education classes }\end{array}$ & $\begin{array}{l}\text { Physical } \\
\text { Education } \\
\text { and Sport } \\
\text { Pedagogy }\end{array}$ & Canada & $\begin{array}{l}\text { Explore how } \\
\text { movements } \\
\text { contribute to the } \\
\text { discursive } \\
\text { construction of } \\
\text { masculinities in } \\
\text { secondary school }\end{array}$ & $\begin{array}{l}\text { Poststructural } \\
\text { theoretical } \\
\text { framework }\end{array}$ & $\begin{array}{l}\text { Masculinities were constituted in the } \\
\text { moments between formal teaching and } \\
\text { activities within the classrooms. }\end{array}$ \\
\hline
\end{tabular}




\begin{tabular}{|c|c|c|c|c|c|c|c|}
\hline \multicolumn{8}{|c|}{ Appendix: Included Articles } \\
\hline Author & Year & Title & Journal & $\begin{array}{l}\text { First author's } \\
\text { country of } \\
\text { employment }\end{array}$ & $\begin{array}{l}\text { Purpose/ aim of } \\
\text { study }\end{array}$ & $\begin{array}{l}\text { Theoretical } \\
\text { perspectives } \\
\text { referred to }\end{array}$ & Findings \\
\hline & & $\begin{array}{l}\text { through body } \\
\text { movements }\end{array}$ & & & $\begin{array}{l}\text { physical education; } \\
\text { specifically, how } \\
\text { body movements } \\
\text { constitute } \\
\text { masculinities. }\end{array}$ & & \\
\hline $\begin{array}{l}\text { Kirk \& } \\
\text { Tinning }\end{array}$ & 1994 & $\begin{array}{l}\text { Muscularity, the } \\
\text { Habitus and the } \\
\text { Social } \\
\text { Construction of } \\
\text { Gender: Towards } \\
\text { a gender-relevant } \\
\text { physical education }\end{array}$ & $\begin{array}{l}\text { Sociology } \\
\text { of Health \& } \\
\text { Illness }\end{array}$ & Australia & $\begin{array}{l}\text { Illustrate the ways in } \\
\text { which popular } \\
\text { physical culture is } \\
\text { appropriated, } \\
\text { reconstructed and } \\
\text { accommodated } \\
\text { within adolescents' } \\
\text { lifestyles. }\end{array}$ & $\begin{array}{l}\text { Social } \\
\text { construction }\end{array}$ & $\begin{array}{l}\text { Many girls and some boys experience } \\
\text { degrees of disembodiment in physical } \\
\text { education lessons as a strategy for the } \\
\text { protection of self-identity. Many are } \\
\text { hindered in appropriating the resource } \\
\text { popular physical culture to lead active } \\
\text { healthy lifestyles. }\end{array}$ \\
\hline Lambert & 2018 & $\begin{array}{l}\text { Girls on fire: } \\
\text { alternative } \\
\text { movement } \\
\text { pedagogies to } \\
\text { promote } \\
\text { engagement of } \\
\text { young women in } \\
\text { physical activity }\end{array}$ & $\begin{array}{l}\text { Sport, } \\
\text { Education } \\
\text { and Society }\end{array}$ & Australia & $\begin{array}{l}\text { Extend recent } \\
\text { discussions around } \\
\text { 'embodied learning' } \\
\text { and 'valuing } \\
\text { movement' in PE by } \\
\text { exploring the } \\
\text { educative potential } \\
\text { of 'in' movement } \\
\text { experiences of a } \\
\text { group of young } \\
\text { women. Inform } \\
\text { 'embodied } \\
\text { pedagogies' with the } \\
\text { potential to re- } \\
\text { inspire and reengage } \\
\text { young women in PE } \\
\text { (p. } 721 \text { ). }\end{array}$ & $\begin{array}{l}\text { Feminist and } \\
\text { poststructural } \\
\text { approaches } \\
\text { Phenomenology/S } \\
\text { ensory } \\
\text { ethnography }\end{array}$ & $\begin{array}{l}\text { Young women conceive of their bodie } \\
\text { conscious collective organism that } \\
\text { simultaneously pays cognitive, physic } \\
\text { social attention to its environment and } \\
\text { other material and non-material object } \\
\text { This attentiveness occurs by thinking, } \\
\text { feeling, sensing and deriving pleasure } \\
\text { movement with blurred boundaries be } \\
\text { mind-body (p.721). }\end{array}$ \\
\hline Light & 2007 & $\begin{array}{l}\text { Re-examining } \\
\text { Hegemonic } \\
\text { Masculinity in } \\
\text { High School } \\
\text { Rugby: The Body, } \\
\text { Compliance and } \\
\text { Resistance }\end{array}$ & Quest & Australia & $\begin{array}{l}\text { Examines the ways } \\
\text { in which variation, } \\
\text { diversity, and } \\
\text { resistance can be } \\
\text { found operating } \\
\text { within a particular } \\
\text { form of hegemonic } \\
\text { masculinity. }\end{array}$ & $\begin{array}{l}\text { Hegemonic } \\
\text { masculinity } \\
\text { theory: Connell } \\
\text { and } \\
\text { Messerschmidt } \\
(2005)\end{array}$ & $\begin{array}{l}\text { There was a significant gap between } t \\
\text { traditional masculinity at the school at } \\
\text { ability and inclination of most of the } b \\
\text { practice it. } \\
\text { Suggests that a hegemonic pattern of } \\
\text { masculinity was deeply embedded in } \\
\text { habitus of the boys in the rugby team. }\end{array}$ \\
\hline $\begin{array}{l}\text { Lindgren \& } \\
\text { Barker }\end{array}$ & 2019 & $\begin{array}{l}\text { Implementing the } \\
\text { Movement- } \\
\text { Oriented } \\
\text { Practising Model } \\
\text { (MPM) in } \\
\text { physical } \\
\text { education: } \\
\text { empirical findings } \\
\text { focusing on } \\
\text { student learning } \\
\end{array}$ & $\begin{array}{l}\text { Physical } \\
\text { Education } \\
\text { and Sport } \\
\text { Pedagogy }\end{array}$ & Sweden & $\begin{array}{l}\text { To discern how } \\
\text { students' movement } \\
\text { dispositions develop } \\
\text { when they take part } \\
\text { in lessons guided by } \\
\text { the Movement- } \\
\text { Oriented Practising } \\
\text { Model (MPM). }\end{array}$ & $\begin{array}{l}\text { Sloterdijk's } \\
\text { (2013) } \\
\text { philosophical } \\
\text { framework } \\
\text { Gilbert Ryle's } \\
\text { (2009) } \\
\text { conceptualization } \\
\text { of knowing and } \\
\text { dispositions. }\end{array}$ & $\begin{array}{l}\text { Dispositional development involved c } \\
\text { in: the ways students moved, the stude } \\
\text { approaches to practicing and performi } \\
\text { and the ways the students described } \\
\text { themselves and their learning. }\end{array}$ \\
\hline lisahunter & 2004 & $\begin{array}{l}\text { Bourdieu and the } \\
\text { social space of the } \\
\text { PE class: } \\
\text { reproduction of } \\
\text { Doxa through } \\
\text { practice }\end{array}$ & $\begin{array}{l}\text { Sport, } \\
\text { Education } \\
\text { and Society }\end{array}$ & Australia & $\begin{array}{l}\text { Describe the social } \\
\text { space of a physical } \\
\text { education class } \\
\text { (where subjectivities } \\
\text { are constructed and } \\
\text { negotiated in } \\
\text { particular ways in } \\
\text { dialogue with the } \\
\text { available discursive } \\
\text { spaces) }\end{array}$ & Bourdieu & $\begin{array}{l}\text { Many students regarded PE to be } \\
\text { synonymous with sport: PE acted as a } \\
\text { structure constituting and constituted } 1 \\
\text { agents on macro and micro level. } \\
\text { The subject positions rewarded in PE } \\
\text { the ideal body type (not being fat), an } \\
\text { good student. }\end{array}$ \\
\hline
\end{tabular}




\begin{tabular}{|c|c|c|c|c|c|c|c|}
\hline \multicolumn{8}{|c|}{ Appendix: Included Articles } \\
\hline Author & Year & Title & Journal & $\begin{array}{l}\text { First author's } \\
\text { country of } \\
\text { employment }\end{array}$ & $\begin{array}{l}\text { Purpose/ aim of } \\
\text { study }\end{array}$ & $\begin{array}{l}\text { Theoretical } \\
\text { perspectives } \\
\text { referred to }\end{array}$ & Findings \\
\hline $\begin{array}{l}\text { Mikalsen \& } \\
\text { Lagestad }\end{array}$ & 2020 & $\begin{array}{l}\text { What's in it for } \\
\text { me? Young } \\
\text { teenagers' } \\
\text { meaning-making } \\
\text { experiences of } \\
\text { movement } \\
\text { activities }\end{array}$ & $\begin{array}{l}\text { Sport, } \\
\text { Education } \\
\text { and Society }\end{array}$ & Norway & $\begin{array}{l}\text { Shed light on the } \\
\text { lifeworld of thirteen- } \\
\text { year-olds with high } \\
\text { and low activity } \\
\text { levels in relation to } \\
\text { movement activities. }\end{array}$ & $\begin{array}{l}\text { Physical literacy } \\
\text { (Whitehead) } \\
\text { Phenomenology }\end{array}$ & $\begin{array}{l}\text { Meaning-making, in terms of interpla } \\
\text { self-regulation, expressed a partly pol } \\
\text { picture of the lifeworld of young peop } \\
\text { high and low activity levels in relation } \\
\text { movement activities. Among those wi } \\
\text { activity 'finding oneself in the activity } \\
\text { be better', 'interplay', and 'self-regula } \\
\text { were identified as meaning-making } \\
\text { dimensions. Among those with low ac } \\
\text { 'ambivalence', 'to be good', 'interplay } \\
\text { 'self-regulation' were identified as me } \\
\text { making dimensions. }\end{array}$ \\
\hline $\begin{array}{l}\text { Nyberg, } \\
\text { Barker \& } \\
\text { Larsson }\end{array}$ & 2019 & $\begin{array}{l}\text { Exploring the } \\
\text { educational } \\
\text { landscape of } \\
\text { juggling - } \\
\text { challenging } \\
\text { notions of ability } \\
\text { in physical } \\
\text { education }\end{array}$ & $\begin{array}{l}\text { Physical } \\
\text { Education } \\
\text { and Sport } \\
\text { Pedagogy }\end{array}$ & Sweden & $\begin{array}{l}\text { Further advance the } \\
\text { knowledge base of } \\
\text { what movement } \\
\text { capability can mean } \\
\text { within the context of } \\
\text { PE. }\end{array}$ & $\begin{array}{l}\text { Ryle's and } \\
\text { Polanyi's notions } \\
\text { of knowing } \\
\text { and learning }\end{array}$ & $\begin{array}{l}\text { Findings of the investigation suggest } \\
\text { the group of students, four significant } \\
\text { of knowing the landscape of juggling } \\
\text { important: grasping a pattern; graspin } \\
\text { rhythm; preparing for the next throw } \\
\text { catch and navigating one's position an } \\
\text { throwing. }\end{array}$ \\
\hline $\begin{array}{l}\text { Nyberg \& } \\
\text { Carlgren }\end{array}$ & 2015 & $\begin{array}{l}\text { Exploring } \\
\text { capability to move } \\
\text { - somatic } \\
\text { grasping of house- } \\
\text { hopping }\end{array}$ & $\begin{array}{l}\text { Physical } \\
\text { Education } \\
\text { and Sport } \\
\text { Pedagogy }\end{array}$ & Sweden & $\begin{array}{l}\text { Explore what it } \\
\text { means to be able to } \\
\text { move in different } \\
\text { ways. What does it } \\
\text { mean, from the } \\
\text { perspective of the } \\
\text { learners, to know } \\
\text { how to carry out a } \\
\text { specific movement? } \\
\text { How could this } \\
\text { insight contribute to } \\
\text { the planning of } \\
\text { developing learners' } \\
\text { capability to move } \\
\text { in different ways? } \\
\text { (p.612) }\end{array}$ & $\begin{array}{l}\text { Gilbert Ryle: } \\
\text { «knowing how» } \\
\text { Phenomenography } \\
\text { Variation Theory }\end{array}$ & $\begin{array}{l}\text { Teaching and learning movements car } \\
\text { facilitated through developing a langu } \\
\text { articulating the knowing involved in } \\
\text { grasping movements. Knowing a mov } \\
\text { as something, for example, 'as a high } \\
\text { in a tube,' 'as a house-hop with a trail } \\
\text { 'as a house-hop in a small cell' can se } \\
\text { metaphorical articulations which in tu } \\
\text { could be seen as creating a certain me } \\
\text { of a movement. The knowing involve } \\
\text { house-hopping as well as other ways } \\
\text { moving can be seen as somatic graspil } \\
\text { comprising mental and physical skills } \\
\text { integrated whole. }\end{array}$ \\
\hline $\begin{array}{l}\text { Nyberg \& } \\
\text { Meckbach }\end{array}$ & 2017 & $\begin{array}{l}\text { Exergames 'as a } \\
\text { teacher' of } \\
\text { movement } \\
\text { education: } \\
\text { exploring } \\
\text { knowing in } \\
\text { moving when } \\
\text { playing dance } \\
\text { games in physical } \\
\text { education }\end{array}$ & $\begin{array}{l}\text { Physical } \\
\text { Education } \\
\text { and Sport } \\
\text { Pedagogy }\end{array}$ & Sweden & $\begin{array}{l}\text { Explore and } \\
\text { articulate what there } \\
\text { is to know, from the } \\
\text { mover's perspective, } \\
\text { when knowing how } \\
\text { to move in specific } \\
\text { ways when playing } \\
\text { exergames (dance } \\
\text { games) (p.1). }\end{array}$ & $\begin{array}{l}\text { Gilbert Ryle: } \\
\text { «knowing how» } \\
\text { Phenomenography }\end{array}$ & $\begin{array}{l}\text { The result of the phenomenographic a } \\
\text { shows different ways of knowing the } \\
\text { movements as well as what aspects ar } \\
\text { discerned and experienced simultaneo } \\
\text { by the students. In other words, these } \\
\text { also describe knowing in terms of } \\
\text { discerning, discriminating and differe } \\
\text { aspects of a phenomenon (p.10). }\end{array}$ \\
\hline O'Connor & 2018 & $\begin{array}{l}\text { Exploring a } \\
\text { pedagogy for } \\
\text { meaning-making } \\
\text { in physical } \\
\text { education }\end{array}$ & $\begin{array}{l}\text { European } \\
\text { Physical } \\
\text { Education } \\
\text { Review }\end{array}$ & Australia & $\begin{array}{l}\text { Present a series of } \\
\text { steps that provide } \\
\text { detail about a } \\
\text { meaning-making } \\
\text { process undertaken } \\
\text { during a physical } \\
\text { education class. } \\
\text { Highlight the } \\
\text { pedagogical } \\
\text { challenges and the } \\
\text { opportunities these } \\
\text { create when } \\
\text { establishing learning } \\
\text { environments that } \\
\text { consider how } \\
\text { students individually } \\
\text { and collectively } \\
\text { value movement. }\end{array}$ & Phenomenology & $\begin{array}{l}\text { Setting aside time for reflection and } \\
\text { the generation of rich movement narra } \\
\text { aligned to a 'first rush of movement', } \\
\text { shed light on what students find mean } \\
\text { 'in' movement in ways that link PE or } \\
\text { experiences across varying social and } \\
\text { environmental contexts. Through givi } \\
\text { priority to bodily understandings of } \\
\text { movement as felt, sensory experience, } \\
\text { participants were able to express mear } \\
\text { across a wide range of movement con }\end{array}$ \\
\hline $\begin{array}{l}\text { Oliver \& } \\
\text { Hamzeh }\end{array}$ & 2010 & $\begin{array}{l}\text { 'The boys won't } \\
\text { let us play': Fifth- } \\
\text { grade mestizas } \\
\text { challenge physical } \\
\text { activity discourse } \\
\text { at school }\end{array}$ & $\begin{array}{l}\text { Research } \\
\text { Quarterly } \\
\text { for } \\
\text { Exercise } \\
\text { and Sport }\end{array}$ & The USA & $\begin{array}{l}\text { To understand fifth- } \\
\text { grade mestizas self- } \\
\text { identified barriers to } \\
\text { physical activity, } \\
\text { and to work with } \\
\text { them to develop } \\
\text { strategies for }\end{array}$ & $\begin{array}{l}\text { Feminist, critical } \\
\text { and poststructural } \\
\text { theories } \\
\text { Participatory } \\
\text { action research } \\
\text { (PAR) }\end{array}$ & $\begin{array}{l}\text { The girls were articulate in explaining } \\
\text { they considered a "crisis" of inequity } \\
\text { physical activity opportunities for girl } \\
\text { their school, and they had ideas about } \\
\text { change the inequities they identified ( } \\
\text { By publicly challenging the conflictin } \\
\text { racialized and gendered discourses, th }\end{array}$ \\
\hline
\end{tabular}




\begin{tabular}{|c|c|c|c|c|c|c|c|}
\hline \multicolumn{8}{|c|}{ Appendix: Included Articles } \\
\hline Author & Year & Title & Journal & $\begin{array}{l}\text { First author's } \\
\text { country of } \\
\text { employment }\end{array}$ & $\begin{array}{l}\text { Purpose/ aim of } \\
\text { study }\end{array}$ & $\begin{array}{l}\text { Theoretical } \\
\text { perspectives } \\
\text { referred to }\end{array}$ & Findings \\
\hline & & & & & $\begin{array}{l}\text { challenging these } \\
\text { barriers (p.38). }\end{array}$ & & $\begin{array}{l}\text { were successful at bringing about char } \\
\text { subtle ways (p.49-50). }\end{array}$ \\
\hline $\begin{array}{l}\text { Oliver, } \\
\text { Hamzeh \& } \\
\text { McCaughtry }\end{array}$ & 2009 & $\begin{array}{l}\text { Girly girls can } \\
\text { play games / Las } \\
\text { niñas } \\
\text { pueden jugar } \\
\text { tambien: Co- } \\
\text { creating a } \\
\text { curriculum of } \\
\text { possibilities with } \\
\text { fifth-grade girls }\end{array}$ & $\begin{array}{l}\text { Journal of } \\
\text { Teaching in } \\
\text { Physical } \\
\text { Education }\end{array}$ & The USA & $\begin{array}{l}\text { Understand 5th- } \\
\text { grade girls' self- } \\
\text { identified barriers to } \\
\text { physical activity and } \\
\text { work with them to } \\
\text { find ways of } \\
\text { negotiating those } \\
\text { barriers in order to } \\
\text { increase their } \\
\text { physical activity } \\
\text { opportunities (p.90). }\end{array}$ & $\begin{array}{l}\text { Feminist, critical } \\
\text { and poststructural } \\
\text { theories } \\
\text { Participatory } \\
\text { action research } \\
\text { (PAR) }\end{array}$ & $\begin{array}{l}\text { The girls explained that being a "girly } \\
\text { hindered their activity participation."( } \\
\text { Through the process of making up anc } \\
\text { playing games, we noticed that the gir } \\
\text { began to resist the idea that being girly } \\
\text { meant that one cannot, or does not, de } \\
\text { being physically active. It was througl } \\
\text { game creation process that the girls be } \\
\text { name and enact alternative possibilitie } \\
\text { their physical activity participation (p. }\end{array}$ \\
\hline $\begin{array}{l}\text { Oliver \& } \\
\text { Lalik }\end{array}$ & 2001 & $\begin{array}{l}\text { The body as } \\
\text { curriculum: } \\
\text { Learning with } \\
\text { adolescent girls }\end{array}$ & $\begin{array}{l}\text { Journal of } \\
\text { Curriculum } \\
\text { Studies }\end{array}$ & The USA & $\begin{array}{l}\text { Use curricular } \\
\text { processes to help the } \\
\text { girls (participants) } \\
\text { understand how they } \\
\text { experience their } \\
\text { bodies in dominant } \\
\text { culture (p.307). }\end{array}$ & $\begin{array}{l}\text { Feminist and } \\
\text { activist } \\
\text { perspectives } \\
\text { Activist research }\end{array}$ & $\begin{array}{l}\text { Their language revealed the body as a } \\
\text { of collateral they hoped to exchange } \mathrm{f} \\
\text { being noticed and for developing and } \\
\text { maintaining relationships with others } \\
\text { (p.312). Regulating their bodies was a } \\
\text { common practice in the quest for beau } \\
\text { (p.323). }\end{array}$ \\
\hline $\begin{array}{l}\text { Oliver \& } \\
\text { Lalik }\end{array}$ & $\begin{array}{l}2004 \\
\mathrm{a}\end{array}$ & $\begin{array}{l}\text { "The Beauty } \\
\text { Walk, This Ain't } \\
\text { My Topic": } \\
\text { Learning about } \\
\text { critical inquiry } \\
\text { with adolescent } \\
\text { girls }\end{array}$ & $\begin{array}{l}\text { Journal of } \\
\text { Curriculum } \\
\text { Studies }\end{array}$ & The USA & $\begin{array}{l}\text { Examine what } \\
\text { happened when a } \\
\text { researcher worked } \\
\text { with four African- } \\
\text { American middle } \\
\text { school girls to } \\
\text { critique the ways } \\
\text { girls' bodies are } \\
\text { implicated in the } \\
\text { schools' hidden } \\
\text { Curriculum (p.555). }\end{array}$ & $\begin{array}{l}\text { Critical and } \\
\text { feminist } \\
\text { pedagogies } \\
\text { Activist research }\end{array}$ & $\begin{array}{l}\text { Marked by points of engagement and } \\
\text { resistance, the girls' participation vari } \\
\text { among the girls and across inquiry tas } \\
\text { Even so, the girls were able to develo } \\
\text { written and verbal critique against "th } \\
\text { Beauty walk". }\end{array}$ \\
\hline $\begin{array}{l}\text { Oliver \& } \\
\text { Lalik }\end{array}$ & $\begin{array}{l}2004 \\
b\end{array}$ & $\begin{array}{l}\text { Critical inquiry on } \\
\text { the body in girls' } \\
\text { physical education } \\
\text { classes: A critical } \\
\text { poststructural } \\
\text { perspective }\end{array}$ & $\begin{array}{l}\text { Journal of } \\
\text { Curriculum } \\
\text { Studies }\end{array}$ & The USA & $\begin{array}{l}\text { Examine co- } \\
\text { researching with } \\
\text { four African- } \\
\text { American middle } \\
\text { school girls to } \\
\text { critique the ways } \\
\text { girls' bodies are } \\
\text { implicated in the } \\
\text { hidden Curriculum } \\
\text { (p.555). }\end{array}$ & $\begin{array}{l}\text { Critical literacy } \\
\text { Poststructural } \\
\text { feminism } \\
\text { Activist research }\end{array}$ & $\begin{array}{l}\text { Marked by points of engagement and } \\
\text { resistance, the girls' participation vari } \\
\text { among the girls and across inquiry tas } \\
\text { Even so, the girls were able to develop } \\
\text { written and verbal critique against "th } \\
\text { Beauty walk". }\end{array}$ \\
\hline $\begin{array}{l}\text { Rönnqvist, } \\
\text { Larsson, } \\
\text { Nyberg \& } \\
\text { Barker }\end{array}$ & 2019 & $\begin{array}{l}\text { Understanding } \\
\text { learners' sense } \\
\text { making of } \\
\text { movement } \\
\text { learning in } \\
\text { physical education }\end{array}$ & $\begin{array}{l}\text { Curriculum } \\
\text { Studies in } \\
\text { Health and } \\
\text { Physical } \\
\text { Education }\end{array}$ & Sweden & $\begin{array}{l}\text { Describe how } \\
\text { movement learners } \\
\text { made sense of their } \\
\text { own movement } \\
\text { development. }\end{array}$ & $\begin{array}{l}\text { Ryle's and } \\
\text { Polanyi's notions } \\
\text { of knowing } \\
\text { and learning }\end{array}$ & $\begin{array}{l}\text { The results suggest that: the aspects o } \\
\text { moving to which learners attend chan } \\
\text { they learn; learners have a relatively } 1 \\
\text { capacity to verbally articulate what th } \\
\text { learn, and; learners' expectations of id } \\
\text { ways of moving have considerable im } \\
\text { how they come to make sense of their } \\
\text { ways of moving. }\end{array}$ \\
\hline Stride & 2016 & $\begin{array}{l}\text { Centralising } \\
\text { space: the } \\
\text { physical education } \\
\text { and physical } \\
\text { activity } \\
\text { experiences of } \\
\text { South Asian, } \\
\text { Muslim girls }\end{array}$ & $\begin{array}{l}\text { Sport, } \\
\text { Education } \\
\text { and Society }\end{array}$ & The U.K. & $\begin{array}{l}\text { Explore the physical } \\
\text { education (PE) and } \\
\text { physical activity } \\
\text { experiences of a } \\
\text { group of South } \\
\text { Asian, Muslim girls } \\
\text { (p.677). }\end{array}$ & $\begin{array}{l}\text { Middle-ground } \\
\text { theorising (black } \\
\text { feminists: the } \\
\text { matrix of } \\
\text { domination, } \\
\text { intersectionality, }\end{array}$ & $\begin{array}{l}\text { In developing these critical understanc } \\
\text { about PE, many of the girls demonstra } \\
\text { some degree of agency by not automa } \\
\text { embodying and transferring these disc } \\
\text { into broader physical activity spaces. } \\
\text { Moreover, they demonstrate agency fu } \\
\text { by not always accepting the ways thei } \\
\text { physical identities are shaped in PE by } \\
\text { teachers and peers. Instead, they dem } \\
\text { a resistance in the ways they create th } \\
\text { physical activity practices away from } \\
\text { (p.689). }\end{array}$ \\
\hline Sykes & 2009 & $\begin{array}{l}\text { The qBody } \\
\text { Project: From } \\
\text { Lesbians in } \\
\text { Physical }\end{array}$ & $\begin{array}{l}\text { Journal of } \\
\text { Lesbian } \\
\text { Studies }\end{array}$ & Canada & $\begin{array}{l}\text { Understand how } \\
\text { students with "queer } \\
\text { bodies" are } \\
\text { impacted by }\end{array}$ & $\begin{array}{l}\text { Postmodern body } \\
\text { studies: queer } \\
\text { theory, trans }\end{array}$ & $\begin{array}{l}\text { People interviewed for the project talk } \\
\text { about their sexualities in intricate, } \\
\text { multilayered, and shifting ways that c } \\
\text { not be neatly isolated from their embo }\end{array}$ \\
\hline
\end{tabular}




\begin{tabular}{|c|c|c|c|c|c|c|c|}
\hline \multicolumn{8}{|c|}{ Appendix: Included Articles } \\
\hline Author & Year & Title & Journal & $\begin{array}{l}\text { First author's } \\
\text { country of } \\
\text { employment }\end{array}$ & $\begin{array}{l}\text { Purpose/ aim of } \\
\text { study }\end{array}$ & $\begin{array}{l}\text { Theoretical } \\
\text { perspectives } \\
\text { referred to }\end{array}$ & Findings \\
\hline & & $\begin{array}{l}\text { Education to } \\
\text { Queer Bodies } \\
\text { In/Out of School }\end{array}$ & & & $\begin{array}{l}\text { heterosexism, } \\
\text { transphobia, } \\
\text { ableism, and fat } \\
\text { phobia in Canadian } \\
\text { PE. }\end{array}$ & $\begin{array}{l}\text { theory, } \\
\text { postcolonial } \\
\text { theory, crip } \\
\text { theory, and fat } \\
\text { theory }\end{array}$ & $\begin{array}{l}\text { sense of body size, physical capabiliti } \\
\text { social positioning in terms of gender, } \\
\text { queerness, Whiteness, and racializatio }\end{array}$ \\
\hline $\begin{array}{l}\text { Tischler \& } \\
\text { McCaughtry }\end{array}$ & 2011 & $\begin{array}{l}\text { PE Is Not for Me: } \\
\text { When Boys' } \\
\text { Masculinities Are } \\
\text { Threatened }\end{array}$ & $\begin{array}{l}\text { Research } \\
\text { Quarterly } \\
\text { for } \\
\text { Exercise } \\
\text { and Sport }\end{array}$ & The USA & $\begin{array}{l}\text { Examine the } \\
\text { intersection of } \\
\text { masculinities and } \\
\text { school physical } \\
\text { education from the } \\
\text { perspectives of boys } \\
\text { who embodied } \\
\text { masculinities that } \\
\text { were marginalized. }\end{array}$ & $\begin{array}{l}\text { Hegemonic } \\
\text { masculinity theory } \\
\text { Feminist } \\
\text { poststructuralism }\end{array}$ & $\begin{array}{l}\text { Four social practices (content, pedago } \\
\text { teacher-student relationships, and peer } \\
\text { cultures) in these physical education s } \\
\text { privileged some masculinities over otl } \\
\text { The role that embodiment played: hov } \\
\text { boys wore their oppression and in how } \\
\text { bodies resisted marginalizing situation } \\
\text { The boys' bodily features and movem } \\
\text { during physical activities led to being } \\
\text { situated at specific places on the socia } \\
\text { hierarchy. } \\
\text { The study illustrates how the boys wo } \\
\text { oppression through guarded bodies, an } \\
\text { significant ways in which boys embod } \\
\text { resistance. }\end{array}$ \\
\hline $\begin{array}{l}\text { Webb, } \\
\text { Quennerstedt } \\
\text { \& Öhman }\end{array}$ & 2008 & $\begin{array}{l}\text { Healthy bodies: } \\
\text { construction of the } \\
\text { body and health in } \\
\text { physical education }\end{array}$ & $\begin{array}{l}\text { Sport, } \\
\text { Education } \\
\text { and Society }\end{array}$ & The U.K. & $\begin{array}{l}\text { Seek to raise } \\
\text { awareness of areas } \\
\text { for concern in } \\
\text { physical education: } \\
\text { Through what } \\
\text { discourses are } \\
\text { healthy bodies } \\
\text { constructed in } \\
\text { practices of physical } \\
\text { education? What are } \\
\text { the techniques of } \\
\text { power by which } \\
\text { healthy bodies are } \\
\text { constructed? }\end{array}$ & Poststructuralism & $\begin{array}{l}\text { Sweden: fitness and risk constituted th } \\
\text { dominating discourses, in relation to s } \\
\text { the healthy body. Australia: focus on } \\
\text { and fitness discourses to be role mode } \\
\text { the pupils. } \\
\text { The construction of healthy bodies in } \\
\text { privilege a fit healthy body, and an at } \\
\text { healthy body, mainly with normalizati } \\
\text { regulation as techniques of power. }\end{array}$ \\
\hline $\begin{array}{l}\text { Windram- } \\
\text { Geddes }\end{array}$ & 2013 & $\begin{array}{l}\text { Fearing fatness } \\
\text { and feeling fat: } \\
\text { Encountering } \\
\text { affective spaces of } \\
\text { physical activity }\end{array}$ & $\begin{array}{l}\text { Emotion, } \\
\text { Space and } \\
\text { Society }\end{array}$ & The U.K. & $\begin{array}{l}\text { Reveal how } \\
\text { emotional dynamics } \\
\text { of girls' fear and } \\
\text { repulsion of fat } \\
\text { operate within } \\
\text { spaces of physical } \\
\text { activity including } \\
\text { PE. }\end{array}$ & Feminism & $\begin{array}{l}\text { Fears over the potential for fat to be p } \\
\text { on the body became real within the sp } \\
\text { physical activity as fat was used as a t } \\
\text { by both PE teachers and girls' themsel } \\
\text { incite or motivate participation. } \\
\text { Girls shared personal practices of bing } \\
\text { eating and exercise to sustain or achie } \\
\text { thinness. }\end{array}$ \\
\hline Wright & 2000 & $\begin{array}{l}\text { Bodies, Meanings } \\
\text { and Movement: A } \\
\text { Comparison of the } \\
\text { Language of a } \\
\text { Physical } \\
\text { Education Lesson } \\
\text { and a Feldenkrais } \\
\text { Movement Class }\end{array}$ & $\begin{array}{l}\text { Sport, } \\
\text { Education } \\
\text { and Society }\end{array}$ & Australia & $\begin{array}{l}\text { Compare the } \\
\text { language practices } \\
\text { of teachers in a PE } \\
\text { lesson and a } \\
\text { Feldenkrais } \\
\text { movement class, as } \\
\text { these constitute } \\
\text { different forms of } \\
\text { embodiment, } \\
\text { different selves. }\end{array}$ & $\begin{array}{l}\text { Poststructuralist } \\
\text { and linguistic } \\
\text { theory and } \\
\text { methodologies }\end{array}$ & $\begin{array}{l}\text { PE: The body is treated like a tool, sha } \\
\text { what it is told. Body or body parts as } \\
\text { to be moved in particular directions, in } \\
\text { particular manner, to achieve a specifi } \\
\text { skill. The body becomes the instrumer } \\
\text { which the skill is achieved. } \\
\text { Feldenkrais: nothing in the teacher's t } \\
\text { which sets up a particular standard of } \\
\text { movement performance, direct attenti } \\
\text { specific attributes of the body, as thes } \\
\text { sensed through a kinaesthetic scanning } \\
\text { body. }\end{array}$ \\
\hline
\end{tabular}


